\title{
KESENIAN \& MATA PENCAHARIAN \\ - Upaya Seniman Tradisional \& Populer dalam Pemenuhan Nafkah
}

\author{
Nurdien H. Kistanto \\ Fakultas Ilmu Budaya Universitas Diponegoro
}

\begin{abstract}
The traditional and popular artists have their fans, who are associated with levels of society and socio-economic conditions of the artists. Most artists appreciate the arts as a forum for the fulfillment of subsistence and some other artists treat art not merely as the main work in making a living, but as self-actualization and calling in life. Democratization, way of life \& lifestyle have encouraged and accelerated development of new traditions in the arts; industrialization that took place since the early 1970s emphasized the political, policy and strategy choices of economy, trade and commercial business and service-based industries, which are very influential on the lives of the type, variety and artistic tastes. Deployment mode of art with industry and trade system applies to the popular performing arts, both departing from the tradition of Java and the growing management and modern technology, which supported the creation and innovation. With such developments, the traditional artists tend to be marginalized and subsistence efforts to meet with arts performances tend to be unprofitable, while popular artists through the art of business and trade industries tend to prosper. This research, among others, find authentic evidence from the field to confirm the truth of these allegations carefully, so that building theory and the concept of "the efforts of traditional and popular artists in the fulfillment of living life" is a field-based, not based on theory and concepts of the social and cultural sciences - called grand theory. In addition to utilizing the resources of media such as newspapers, magazines and internet websites, techniques of field observation and interviews, as well as in-depth interviews, which are commonly used in qualitative research, the mainstay of this research data collection.
\end{abstract} artists.

Key words: Indonesia, Java, culture, art, livelihood, traditional artists, popular

\section{Pendahuluan}

Seni atau kesenian merupakan unsur kebudayaan penting yang hidup dan berkembang dalam dinamika masyarakat. Dalam masyarakat yang berlapis-lapis kesenian tumbuh dan berkembang memenuhi hajat hidup manusia yang berkaitan dengan pengungkapan, penghayatan dan penerimaan nilai-nilai estetika dan kemanusiaan. Namun, kesenian juga 
menjadi upaya pemenuhan nafkah hidup para seniman dan pihak-pihak yang berkepentingan dengan penciptaan dan penyebaran kesenian. Dalam hal penerimaan kesenian, lapisan masyarakat tertentu dapat menikmati atau mengapresiasi jenis karya seni tertentu, tetapi belum tentu dapat menikmati atau mengapresiasi jenis, karya seni lain. Tradisi seni, menurut Umar Kayam, adalah kesenian yang 'erat' sekali berhubungan dengan pengucapan solidaritas dengan komunitas" (1983:118).

Dalam sistem sosial-budaya tradisional Jawa, masyarakat mengenal lapisan-lapisan sosial wong gede dan wong cilik yang bersumber dari latar belakang masyarakat agraris dan feodal. Demikian pula keseniannya: ada seni halus, seni adikarya yang dibuat dan hidup di dalam tembok-tembok keraton, yang diciptakan dan dinikmati oleh wong gede, bangsawan dan lingkungan dekatnya, dan ada seni kasar, yang berkembang di luar tembok keraton, sebagai kesenian rakyat yang dinikmati, dihargai, atau diapresiasi oleh wong cilik, rakyat kebanyakan atau rakyat jelata. Dua lapisan masyarakat dan dua jenis dan selera seni yang berbeda hidup dan berkembang berdampingan dalam satu peradaban. "One and the same civilization produces simultaneously two such different things" (Satu dan peradaban yang sama menghasilkan secara bersamaan dua hal yang berbeda), ungkap Clement Greenberg dalam Art and Culture (1961: 3).

Tulisan ini membahas kesenian pentas yang hidup dan berkembang dalam masyarakat pedesaan dan perkotaan, khususnya di Jawa Tengah. Dalam kesenian pentas, para seniman tradisional dan populer memiliki penggemar yang berkaitan dengan lapisan masyarakat. Keadaan ini berakibat pada kondisi sosial-ekonomi para seniman pendukung kesenian tradisional dan populer tersebut. Sebagian seniman menghayati laku seninya sebagai wadah 
untuk pemenuhan nafkah hidup, tetapi banyak di antara mereka yang menghayati laku seninya sebagai "panggilan jiwa" atau hobi.

\section{Kesenian Tradisional yang Tersisihkan}

\section{1. Sintren di Dukuh Sirau}

Sintren merupakan salah satu kesenian tradisional masyarakat daerah pesisir Jawa, di wilayah pantai utara Indramayu, Cirebon, Brebes, Tegal, Pemalang, dan Kendal. Seni pentas tradisional sintren mulai dikenal pada awal tahun 1940-an. Sintren merupakan tarian yang berbau mistis dan berdaya magis. Versi pertama, tarian Sintren bersumber dari cerita cinta Putri Sulasih dan Raden Sulandono. Raden Sulandono adalah putra Ki Bahurekso dan Dewi Rantamsari. Raden Sulandono jatuh cinta kepada Putri Sulasih dari desa Kalisalak. Raden Sulandono memutuskan untuk pergi bertapa dan Putri Sulasih memutuskan menjadi penari. Namun, pertemuan mereka masih terus terjadi melalui alam gaib. Pertemuan itu diatur oleh Dewi Rantamsari yang memasukkan roh bidadari ke dalam tubuh Putri Sulasih. Pada saat yang bersamaan Raden Sulandono yang sedang bertapa dipanggil oleh ibunya untuk bertemu dengan Putri Sulasih.

Versi kedua menyebutkan bahwa kesenian Sintren bermula dari kebiasaan kaum ibu dan putra-putrinya yang tengah menunggu suami atau ayah mereka pulang dari mencari ikan di laut dengan memainkan sebuah permainan. Permainan tersebut kemudian berkembang menjadi sebuah mata pencaharian bagi para nelayan. Mereka mementaskan kesenian Sintren secara berkeliling (http://metronews.com) atau di depan suatu rumah tertentu.

Versi ketiga meyakini bahwa Sintren digunakan masyarakat petani sebagai kegiatan ritual yang berhubungan dengan pertanian. Pertunjukan sintren diselenggarakan sebagai 
upaya untuk menghormati sekaligus ungkapan rasa terima kasih kepada Dewi Sri. Di kalangan masyarakat petani di Jawa Dewi Sri adalah dewi kesuburan dan kemakmuran. Oleh karena itu, para petani di Jawa umumnya sangat menghormati keberadaan Dewi Sri. Mereka percaya bahwa Dewi Sri mampu menjaga tanaman padi dari serangan hama dan gangguan lain. Berikut adalah deskripsi pementasan Sintren yang dilakukan di rumah salah seorang penggerak seni, yaitu Andi Rustono (41 th).

Sebelum peralatan pentas disiapkan, pawang Sintren membacakan mantra-mantra terlebih dahulu sebagai permohonan izin kepada penunggu (gaib) tempat pergelaran. Ketika pemain gamelan, sinden, dan penari Sintren siap di atas pentas, sebuah lagu bertajuk Dunung-dunung mulai dilantunkan para sinden secara terus-menerus untuk menarik perhatian penonton agar berdatangan. Sambil menunggu penonton datang, pawang Sintren membakar kemenyan dan membaca mantra-mantra untuk memanggil roh bidadari titisan Dewi Sulasih.

Pementasan berlangsung selama 40 (empat puluh) malam berturut-turut, kecuali saat hujan turun, diganti hari lain. Seperti dikisahkan bahwa Dewi Sulasih, sang penari sintren kerasukan roh bidadari yang bernama Dewi Rantansari dan 39 temannya dari bidadari yang disebut "widodari patangpuluh." Tujuan pementasan selama 40 (empat puluh) malam itu agar calon penari sintren kerasukan bidadari yang jumlahnya 40 (empat puluh). Setelah 40 (empat puluh) kali pementasan, jadilah ia penari sintren yang dipercaya kelak akan mudah mendapatkan jodoh dan dikagumi banyak laki-laki.

Pada setiap pementasannya, tarian yang disajikan penari sintren berbeda dengan tarian yang dibawakan sebelumnya. Ada kalanya yang merasuki tubuh penari adalah bidadari yang 
santun, penari pun akan menari dengan santun. Pada saat yang merasuki tubuh penari adalah bidadari yang "nakal," maka tarian sintren pun akan erotis, dan ketika yang merasuki tubuh penari adalah bidadari yang centil atau manja, tarian yang dibawakan akan menjadi tarian layaknya tari dolanan yang dibawakan anak-anak. Jadi, tarian yang dibawakan oleh penari sintren bergantung pada perangai bidadari yang merasuki tubuhnya.

Ketika penonton mulai berdatangan, mulailah pawang sintren dan seorang calon cantrik mengikat tangan dan kaki si calon penari. Setelah mengikat tangan dan kaki penari, pawang mulai membaca mantra-mantra untuk menghipnotis penari, dan memasukkan penari ke dalam kurungan yang di dalamnya telah tersedia alat rias dan perlengkapan menari, seperti kebaya, kain, selendang, dan sanggul. Beberapa saat setelah penari dimasukkan ke dalam kurungan, kurungan itu bergerak-gerak sendiri, dan salah seorang sinden mulai membuka kurungannya. Ketika kurungan dibuka, penari sudah berpakaian lengkap sebagai penari sintren.

Kurang lebih setelah 30 (tiga puluh) menit penari itu menari tanpa gerakan tangan, datanglah seorang cantrik yang ikut menari lengkap dengan blangkon dan sarung yang dikalungkan di lehernya. Kemudian cantrik tersebut melemparkan sarungnya ke wajah penari, sehingga penari pun jatuh pingsan. Konon ceritanya, cantrik itu adalah titisan Raden Sulandono. Ketika penari jatuh pingsan, pawang dan seorang sinden tadi memasukkannya kembali ke dalam kurungan. Kurang lebih selama 5 (lima) menit, kurungan terbuka dan tali yang mengikat tangan penari sudah terlepas. Penari bergerak menghampiri kerumunan penonton dan sinden mulai mengedarkan tampah, menyambut saweran (pemberian uang) kepada penonton. Cantrik yang lain datang dan menari bersama penari sintren dengan 
memulai memberinya selembar uang kertas yang disimbolkan sebagai saweran, disusul oleh para penonton yang ingin menari bersama juga mengikuti memberi saweran. Selesainya acara saweran, penari mulai menari lagi. Selanjutnya, 2 (dua) orang cantrik datang menghampiri penari itu dan melemparnya dengan sarung yang telah diperciki minyak wangi. Penari pun pingsan untuk kedua kalinya, dan dimasukkan ke dalam kurungan. Tidak lama kemudian, kurungan bergerak dan terbuka, penari Sintren sudah kembali ke keadaan semula, sebelum menari. Penonton dibuat terkesan dengan keajaiban-kejaiban yang disaksikannya sehingga tidak bisa tidak meyakini bahwa Sintren merupakan seni pementasan tradisional khas pantai utara Jawa yang mengandung unsur-unsur magis, yang dalam pementasannya tidak hanya manusia saja yang mendukung acara akan tetapi makhluk gaib di lain dimensi juga turut terlibat. Sintren tidak bisa semata-mata dipandang sebagai kesenian pentas yang digunakan sebagai mata pencaharian melalui hiburan berbau magis kaum agraris, karena dia tidak menjanjikan prospek kesejahteraan ekonomi melalui saweran; Sintren lebih dapat dipahami sebagai ritual dalam kepercayaan terhadap peristiwa gaib sebagai perwujudan kedekatan dan kepedulian masyarakat terhadap lingkungan alam agraris, yang menuntut manusia untuk senantiasa waspada terhadap peristiwa-peristiwa di hadapannya yang tak terduga, baik yang dapat membawa berkah maupun bencana sebagai ujian mental-spiritual dari Yang Maha Kuasa.

\section{2. Cowongan}

Cowongan adalah kesenian tradisional untuk ritual minta hujan pada masyarakat Banyumas dan sekitarnya. Cowongan dilakukan agar penyelengara dan lingkungannya memperoleh bantuan dari Dewi Sri atau dewi padi, lambang kemakmuran dan 
kesejahteraan. Melalui doa-doa, Dewi Sri akan datang melalui lengkung bianglala (pelangi) ke bumi sambil menurunkan hujan. Dilihat dari asal kata cowongan, istilah ini berasal dari cowong dan akhiran an dari bahasa Jawa yang sinonim dengan kata perong, cemong atau therok yang artinya belepotan di bagian wajah. Perong, cemong, atau therok lebih bersifat pasif (tidak sengaja) sedangkan cowongan bersifat aktif (disengaja). Jadi cowongan artinya sesuatu yang dengan sengaja dilakukan untuk menghias wajah, yaitu wajah irus atau siwur (nyiru) yang dihias sedemikian rupa agar menyerupai manusia, sebagai boneka.

Peralatan kesenian cowongan antara lain siwur (gayung dari bathok kelapa), payung, tandu, bunga, kemenyan dan seperangkat gamelan. Pemain sedikitnya 19 (sembilanbelas) orang yang terdiri atas 4 (empat) pemandu, 1 (satu) bidadari, 4 (empat) dayang, 1 (satu) dalang, 1 (satu) iblis, 4 (empat) penduduk, dan 4 (empat) wiyogo. Pementasan cowongan diawali dengan musik gamelan. kemudian dalang membawa sesaji dan boneka cowong ke tengah panggung. Dalang kemudian membaca mantera dan sesaat kemudian pemegang cowong mengalami trans, dengan gerakan tanpa kesadaran diri. Setelah itu muncul penari yang melambangkan bidadari dan dayang-dayang turun dari pelangi dengan membawa hujan. Pementasan berakhir setelah para penari ke luar dari panggung.

Di Banyumas ada kelompok kesenian cowongan dengan nama "Cowongan Sewu," yang diprakarsai oleh Titut Edi Purwanto (45 tahun). "Cowongan Sewu” didirikan pada tahun 2006, dengan tujuan ingin melestarikan tradisi budaya Banyumasan yang mulai dilupakan generasi sekarang. Cowongan menunjukkan bahwa nenek moyang Banyumas merupakan pujangga karena mantra tradisi cowongan hakikatnya adalah syair yang indah. Bagi masyarakat Banyumas, kesenian cowongan adalah jiwa, artinya berkesenian cowongan 
dapat merasakan kepuasan batin; bahkan bagi seniman, berkesenian cowongan dapat melepaskan emosi.

Frekuensi pementasan yang sangat rendah dan jumlah honor yang tidak seberapa itu membuat kesenian cowongan tidak mungkin dijadikan sumber penghasilan. Hasil berkesenian cowongan tidak bisa mencukupi kebutuhan hidup anggota perkumpulan cowongan. Kondisi yang demikian itu berpotensi melemahkan semangat para pelaku seni dalam melestarikan cowongan. Hal yang masih menjadi dorongan semangat dari para pelaku seni cowongan adalah dukungan utama dari para keluarga mereka. Para seniman yang tergabung dalam kelompok kesenian ini pada umumnya adalah bagian keluarga yang memiliki semangat untuk melestarikan tradisi cowongan di Banyumas. Atas dukungan itulah mereka sering dengan rela mementaskan kesenian ini walaupun dengan honor yang tidak seberapa.

\section{3. Lengger: Tayub, Ledhek, Tledhek atau Ronggeng}

Lengger adalah kesenian rakyat Banyumas berupa tarian yang dibawakan oleh penari wanita dengan iringan musik khas Banyumasan, calung. Peralatan musik berupa kendang, calung, gambang barung, gambang penerus, slentheng, kenong dan gong. Jumlah pemain 10 (sepuluh) orang: 3 (tiga) penari lengger, 6 (enam) penabuh calung, 1 (satu) sinden. Ada yang menyebut lengger dengan ronggeng; di daerah lain lengger atau ronggeng disebut tayub, ledhek atau tledhek.

Pementasan diawali oleh musik calung Banyumasan. Selanjutnya, penari lengger masuk panggung, mulai menari dan menyanyi. Penonton segera menyambutnya dengan naik panggung pementasan untuk menari sambil menyelipkan saweran berupa uang kertas di 
bagian atas tubuh penari. Dalam pementasan lengger semakin banyak saweran didapat, penari semakin erotis dalam menari bersama penonton. Salah satu kelompok lengger yang berasal dari Banyumas adalah Lengger Kencana Laras. Lengger ini berdiri pada tahun 1989 dan beralamat di Jl. Tanjung RT 02/RW II Purwokerto, Banyumas. Menurut pengelola Lengger Kencana Laras, lengger adalah "hiburan tradisional yang memiliki ruh Banyumasan.” Pengarang novel asal Banyumas, Ahmad Thohari, mempopulerkannya dengan sebutan ronggeng dalam novelnya yang berjudul Ronggeng Dukuh Paruk, yang kemudian bahkan difilemkan berjudul Sang Penari. Di daerah-daerah lain seperti Blora, Purwodadi, dan pantai utara Jawa kegiatan pementasan kesenian yang sama disebut tayub, ledhek atau tledhek.

Pada tahun 1990-an kesenian pentas ini diminati masyarakat dan sering diundang dalam acara-acara seperti hajatan, 17-an, dan mewakili daerah Banyumas ke luar daerah. Akan tetapi, sekarang kesenian ini tampaknya kurang diminati oleh masyarakat sehingga sebagai mata pencaharian bagi para penari dan pendukungnya kurang menguntungkan. Meski pun demikian, bagi mereka bermain lengger adalah panggilan jiwa: "menjadi lengger itu karena indang (wahyu)," kata pemain lengger. Yang menjadi beban sebagai penari lengger adalah gunjingan bahwa lengger identik dengan wanita penggoda.

Pada tahun 2006 penulis memasuki satu kampung di sebelah timur area wisata alam "Bleduk Kuwu" Purwodadi dan menemukan beberapa gang kampung yang pemukimnya sejumlah penari ledhek. Pada satu gang di kampung bermukim berpencaran 4 (empat) penari ledhek. Salah satu penari muda bersuami tampak paling menarik dengan kulit putih bersih mengaku pada saat-saat tertentu, terutama di musim panen dia sering diundang menari 
sampai 3 (tiga) malam berturut-turut di satu rumah penanggap dengan bayaran 5 (lima) juta rupiah atau lebih. Pada waktu kami wawancara suaminya menemani di sebelahnya dan tampak gembira, bahkan bangga dengan keberhasilan isterinya; rumahnya bertembok bercampur kayu jati tergolong mewah dengan tiang-tiang kayu jati cukup besar, berlantai

marmer. Beberapa penari lain yang kami temui mengaku mendapat honor antara Rp. 150 ribu sampai Rp 300 ribu tiap kali mendapat undangan dan tidak sesering penari yang pertama; rumah-rumah mereka tergolong biasa, bahkan salah satu yang paling muda, berusia sekitar 20 an tahun dari 3 (tiga) penari itu, mendiami rumah yang berdinding papan tua, tampak memprihatinkan. Kampung tersebut memang sejak lama dikenal sebagai kampung bermukim para ledhek, bahkan seorang ledhek legendaris yang sudah sepuh dan tidak aktif lagi yang tinggal di kampung tersebut menyisakan bekas-bekas kejayaan berupa patung penari yang terbuat dari beton bertulang di depan rumahnya yang tampak tak terawat.

\section{4. Kuda Lumping atau Jaranan dan Ebeg}

Kuda lumping atau Jaranan dan ebeg merupakan bentuk seni gerak, suara, dan musik yang berpadu membawakan sebuah cerita. Sesuai namanya, kesenian ini menggambarkan sekelompok prajurit yang tengah menunggang kuda. Dengan menggunakan kuda-kudaan yang terbuat dari anyaman bambu, para pelaku yang berperan sebagai prajurit melakukan tarian yang ritmis, agresif, disertai dengan adegan-adegan magis, seperti kesurupan, memakan pecahan kaca, membakar diri, dan dipukul dengan pecut. Dalam satu pementasan, jumlah peraga sekitar 10 (sepuluh) orang, masing-masing memiliki peran seperti penabuh 
gamelan, pesinden, dan penari. Di beberapa tempat pementasan ini berlangsung selama tujuh jam.

Untuk mendirikan sebuah kelompok seni kuda lumping atau ebeg, seseorang harus merekrut anggota yang jumlahnya tidak sedikit. Menurut Murdowo, para anggota kelompok kesenian yang dipimpinnya berasal dari masyarakat golongan ekonomi bawah. Mereka bekerja sebagai buruh tani, peternak, atau bekerja di tambak. Penghasilan yang mereka peroleh dari pekerjaan bertani hanya cukup untuk memenuhi kebutuhan hidup sehari-hari, bahkan kadang-kadang kurang. Para pelaku kesenian kuda lumping ini pendapatannya ratarata tidak sampai dua juta per bulan. Salah satu anggota kuda lumping "Turonggo Ceto," Titik Rahayu, bekerja sebagai buruh pabrik dengan penghasilan kurang lebih Rp 300.000,per bulan.

Dari gambaran keadaan ekonomi mereka, para pendiri dan pelaku seni kuda lumping rata-rata hidup secara pas-pasan. Upaya mereka untuk mendirikan kelompok kesenian dan menjalani kegiatan seni kuda lumping ini tidak dapat digunakan sebagai sarana untuk mencari tambahan penghasilan karena secara ekonomis jauh dari cukup. Sekali pentas, kelompok kesenian ini rata-rata mendapat imbalan satu setengah sampai dua juta. Jumlah tersebut digunakan untuk biaya perjalanan, sewa sound system, dan lain-lain. Sisanya baru dibagikan kepada para pelaku yang rata-rata mendapat Rp 50.000,- setiap anggota. Bahkan ada kelompok kesenian yang tidak memberi honor kepada para anggotanya karena sisa uang yang diperoleh mereka sepakati untuk dimasukkan ke dalam kas kelompok.

Mendirikan kelompok kesenian kuda lumping bagi pelaku seni ini semata-mata karena mereka merasa terpanggil untuk melestarikan jenis kesenian tersebut. Para pendiri kesenian 
kuda lumping ini pada umumnya adalah pelaku seni itu sendiri yang mewarisi darah seni secara turun-temurun. Dengan demikian, motif mereka berkesenian ini betul-betul sebagai pengabdian terhadap kesenian dan penyaluran hobi. Bagi mereka kuda lumping merupakan warisan yang secara turun-temurun berusaha dipelihara oleh generasi sebelumnya sehingga mereka pun terpanggil untuk melakukan hal yang sama. Sikap serupa juga ditunjukkan oleh para pelaku seni kuda lumping tersebut. Mereka yang bergabung dalam suatu kelompok kesenian kuda lumping pada umumnya ingin menyalurkan hobi dan tergerak untuk ikut melestarikan jenis kesenian tersebut. Rata-rata mereka memiliki darah seni baik di bidang seni suara, seni gerak, ataupun sebagai penabuh gamelan pengiring. Dengan demikian, mereka rela diberi penghargaan dalam jumlah uang yang tidak banyak, yaitu rata-rata Rp 50.000,- setiap kali pentas, bahkan ada kelompok yang para anggotanya sepakat untuk tidak menerima upah.

Di dalam berkesenian, para pendiri dan pelaku seni tersebut memiliki harapan agar pengabdiannya terhadap kehidupan seni tradisional membuahkan hasil, yaitu seni tradisional tetap bertahan dan lebih dikenal oleh masyarakat luas. Harapan ini didasarkan pada keprihatinan mereka bahwa dewasa ini berbagai kesenian tradisional di Indonesia mulai ditinggalkan oleh masyarakat. Kesenian kuda lumping ini masih memiliki pendukung, yang tampak dari jumlah penonton setiap kali pementasan.

Sangat sederhana adalah pementasan kelompok jaranan di jalanan dengan anggota 3 (tiga) orang laki-laki yang setiap hari mencari nafkah dengan menyusuri jalanan dan memasuki kompleks perumahan pagi sampai siang atau sore, dengan upah sesuai pemberian. Dari 1 (satu) kelompok beranggotakan 3 (tiga) orang penari jaranan laki-laki 
diperoleh pengakuan masing-masing bisa mendapatkan antara Rp. 25.000 sampai Rp. 50.000 per hari tergantung peruntungan.

\section{5. Ebeg "Janur"}

Di Banyumas terdapat sebuah kelompok seni ebeg yang diberi nama "Janur." Kelompok ini berdiri pada tanggal 5 Mei 1995 dan diketuai oleh Sugeng Santoso, alias Cueng Tato. Markas seni ebeg "Janur" ini adalah kediaman Cueng Tato sendiri, yaitu di Jl. Tipar Baru Gg. III No. 71 Kranji Purwokerto Timur Banyumas. Pak Cueng adalah seorang pelukis tato, baik yang permanen maupun yang sementara. Selain itu, ia juga seorang tukang pembuat taman yang sering dimintai masyarakat untuk memperindah rumah. Dalam kesenian ebeg "Janur," terdapat seorang sinden yang bernama Sunarti dan penari ebeg yang bernama Wahyu. Bu Narti adalah penjual nasi rames di warung kecilnya. Dari keuntungan penjualan nasi tersebut dia memenuhi kebutuhan keluarga. Sementara itu, Wahyu adalah tukang bangunan yang sering mendapat order membangun, memperbaiki, atau merenovasi rumah. Dari pekerjaan tersebut Pak Wahyu menghidupi keluarganya. Ditilik dari jumlah penghasilan mereka tersebut, ketiga pelaku seni ini sebenarnya termasuk dalam kategori masyarakat dengan penghasilan rendah. Kegiatan berkesenian ebeg yang mereka tekuni tetap tidak dapat digunakan sebagai sandaran ekonomi; hal ini disebabkan oleh rendahnya honor yang mereka terima dan juga rendahnya frekuensi tanggapan. Menurut Sunarti, meski tidak mungkin dijadikan sandaran utama, menjadi sinden di pementasan ebeg bisa sedikit menambah pendapatan keluarga.

Berkesenian ebeg menurut Pak Cueng, Pak Wahyu, dan Bu Narti adalah ekspresi jiwa mereka. Mereka juga menyatakan akan berusaha memainkannya sepanjang kesempatan 
diberikan. Sebenarnya, menurut mereka, ada kebahagiaan yang mereka peroleh pada saat mereka memainkan ebeg, terutama ketika mendapat sambutan meriah dari penonton. Kesetiaan mereka dalam memainkan ebeg didasari oleh upaya mereka untuk menjaga kelestarian ebeg. Dengan bermain ebeg Cueng Tato berharap bisa ikut melestarikan seni tradisi yang kini semakin tergerus oleh modernisasi. Sementara itu, menurut Sunarti, selain untuk pelestarian seni tradisional, kesetiaannya terhadap kesenian ebeg adalah juga untuk memberi pengajaran kepada masyarakat melalui lirik-lirik dalam tembang. Ketiga pendukung ebeg ini berkeyakinan, kesenian ebeg akan tetap ada meskipun mengalami perubahan-perubahan dari segi pementasan, seperti pergantian kostum dan koreografi. Pendukung kesenian ebeg adalah keluarga para seniman. Mereka dengan suka rela bergabung dalam kesenian ini demi pelestarian seni-budaya. Oleh karena itu, mereka sering mementaskan kesenian ini tanpa orientasi profit.

Kelompok ebeg "Janur" di Banyumas ini menyatakan bahwa kesenian ebeg adalah bentuk tari tradisional khas Banyumasan dengan properti utama berupa ebeg atau kuda kepang, sesaji, dan gamelan sepangkon. Kesenian ini menggambarkan kegagahan prajurit berkuda dengan segala atraksinya. Pertunjukan ebeg di Banyumas dilengkapi dengan atraksi barongan, penthul, dan cepet dan diiringi oleh gamelan yang lazim disebut bendhe. Di daerah lain seperti Wonosobo, Temanggung, dan Magelang, kesenian ini disebut jaran kepang, kuda lumping atau jathilan, yang merupakan hiburan masyarakat pedesaan agraris. Secara filosofis, ebeg merupakan pengajaran tentang kewajiban rasa syukur kepada Tuhan Yang Maha Esa, sebab manusia yang tidak bersyukur diibaratkan sebagai orang mendem 
(mabuk), laksana ebeg yang menjadi liar tak terkendali dan memakan apapun, termasuk beling (kaca), gabah, dan sebagainya.

Pementasan ebeg "Janur" di Banyumas membutuhkan sedikitnya 19 (sembilan belas) orang pemain yang terdiri atas 8 (delapan) penari ebeg, 7 (tujuh) penabuh gamelan (wiyaga), 2 (dua) sinden, 1 (satu) dalang, dan 1 (satu) pembantu dalang. Pementasan diawali dengan tetabuhan gamelan dengan tembang "Ricik-ricik" dan "Sholawatan" oleh sinden. Tidak lama berselang penari masuk mengikuti irama gamelan. Tarian ini diselingi dagelan dari sang dalang. Setelah dagelan selesai, tarian dilanjutkan kembali. Semakin lama ritme tetabuhan gamelan semakin cepat. Para penari yang mengikuti irama cepat gamelan mengalami "trans" (trance) seperti kerasukan roh halus. Pementasan diakhiri dengan pengusiran roh jahat oleh sang dalang, yang diiringi tembang "Eling-eling” Banyumasan.

\section{6. Kethoprak}

Kethoprak merupakan jenis kesenian yang tidak asing bagi masyarakat Jawa. Kesenian pentas ini merupakan jenis kesenian kelompok yang beranggotakan sampai 70 (tujuh puluh) orang setiap kelompok. Mereka memiliki peran yang beragam, mulai dari sutradara, pemain, penabuh gamelan, penari, sampai penata panggung. Peralatan yang diperlukan pun relatif lebih kompleks daripada jenis kesenian lain. Pengelola kethoprak "Konyik Pati” bernama Susanto memiliki sanggar tari yang juga mengelola kelompok kesenian lain seperti campur sari, barongan, wayang kulit, dan karawitan. Menurut Susanto, kethoprak "Konyik Pati" dikelola secara profesional dan hasilnya dapat digunakan sebagai hasil tambahan bagi para anggotanya. Kebanyakan para anggota kelompok kesenian kethoprak "Konyik Pati" berasal dari masyarakat golongan bawah. Mereka rata-rata lulusan 
sekolah menengah pertama atau tingkatan sekolah yang lebih rendah. Namun, dengan menjadi pemain kethoprak kesejahteraan mereka meningkat, sebab penghasilan mereka sebagai pemain kethoprak cukup besar, yaitu Rp 125.000,- setiap kali pentas. Padahal dalam setahun kelompok ini dapat bermain lebih dari 160 kali.

Karena dikelola secara profesional dan merupakan kesenian dengan anggota yang cukup banyak, kethoprak "Konyik Pati" mematok tarif delapan sampai lima belas juta rupiah sekali pentas. Tarif sebesar itu tidak menyurutkan masyarakat yang hendak menanggap, karena kethoprak ini berhasil menyuguhkan hiburan yang memuaskan bagi para penontonnya. Selain upah yang memadai, kelompok ini juga mendapat penghargaan dalam wujud lain, seperti sering meraih juara di setiap perlombaan baik di tingkat Jawa Tengah maupun nasional dan memperoleh kesempatan untuk pentas di televisi, seperti TVRI Jawa Tengah, TVRI Surabaya, Indosiar, dan TPI. Namun, kelompok kethoprak “Konyik Pati” ini merasa bahwa pemerintah kurang mendukung kiprah mereka.

Sebagai pelaku seni, para anggota kelompok ini juga memilik harapan dan cita-cita. Berkesenian menurut mereka adalah upaya untuk mengekspresikan bakat dan dorongan seni. Di samping itu, mereka juga berharap kethoprak dapat dijadikan sebagai mata pencaharian sehingga dapat digunakan untuk memenuhi kebutuhan keluarga. Mereka berharap kesenian kethoprak tetap bertahan sehingga mereka dapat terus berkesenian. Bermain kethoprak menurut mereka adalah wujud pengabdiannya terhadap kebudayaan tradisional Jawa Tengah.

\section{Seni Musik Modern}


Musik modern berkembang dalam berbagai bentuk, seperti solo organ, band, perkusi, paduan suara, dan vocal group, yang ditandai oleh ketidakhadiran unsur tradisional, khususnya pada alat musik yang dimainkan. Selain itu, musik modern ini juga memiliki jangkauan yang lebih luas, yaitu hampir ada di seluruh wilayah Indonesia. Berikut disampaikan mengenai beberapa bentuk musik modern tersebut.

\section{1. Solo Organ}

Solo organ atau organ tunggal pada dasarnya, sesuai dengan namanya, dimainkan hanya dengan satu alat musik, yaitu keyboard atau organ. Pada umumnya, lagu yang dimainkan adalah lagu-lagu pop Indonesia, pop manca negara, ndangdut, campur sari, dan pop daerah. Jenis musik ini sangat populer karena dalam pementasannya penyanyi dapat mengajak penonton untuk berpartisipasi. Di samping itu, jenis kesenian ini sangat simpel dari sudut pandang persiapan dan peralatan. Dengan kesederhaan ini tarif yang dikenakan pun terjangkau untuk lapisan masyarakat menengah ke bawah. Dua dari sekian banyak satuan solo organ yang berasal dari Banyumas adalah "Harmony entertainment" dan "Setia Laras."

Pendiri "Harmony entertainment" bernama Suparno, yang menjadikan kesenian pentas ini sebagai mata pencaharian. Oleh karena itu, hidupnya sangat bergantung pada keberlangsungan permainan musik yang dikelolanya tersebut. Organ tunggal yang dikelola Suparno ini sangat produktif. Dalam setahun, kelompok ini bisa pentas lebih dari 100 (seratus) kali dengan tarif antara 3 (tiga) sampai 4 (empat) juta rupiah sekali tampil. Dari jumlah itu, Suparno sebagai pengelola sekaligus pemain keyboard mendapatkan bagian antara 1 (satu) sampai 2 (dua) juta rupiah. Bagi Suparno, jumlah tersebut cukup untuk 
memenuhi kebutuhan hidupnya. Sebagai seorang musisi, Suparno bercita-cita agar usaha yang dikelolanya dapat terjaga keberlangsungannya. Oleh karena itu, dalam perjalanannya Suparno juga melakukan regenerasi, yaitu mulai melibatkan anak-anaknya dalam usaha organ tunggal tersebut.

Kiprah kelompok organ tunggal yang kedua, yaitu "Setia Laras," yang didirikan oleh Susilo, yang bekerja sebagai Pegawai Negeri Sipil (PNS). Dengan dorongan seni yang sangat kuat dan kepandaian bermain keyboard, Susilo mendirikan "Setia Laras." Dalam satu tahun, kelompok ini bisa diundang untuk berpentas sebanyak lebih dari 20 (dua puluh) kali dengan tarif Rp 1.500.000,- sekali pentas. Jumlah tersebut digunakan untuk membayar penyanyi, MC, transport, dan sewa sound system. Sebagai pemain keyboard, Susilo mendapat bagian Rp 350.000,- setiap kali pentas. Pendapatan tambahan ia peroleh dari hasil penyewaan sound system.

\section{2. Band}

Masyarakat Indonesia mudah menerima bentuk kesenian dari luar, salah satunya adalah kelompok musik band. Musik band masuk ke Indonesia sekitar tahun 60-an, yakni pada era kejayaan awal kelompok musik dari Inggris The Beatles. Pada tahun-tahun tersebut berdiri dan menjadi populer kelompok musik dua bersaudara di Jakarta, "Koes Bersaudara." Musik band pada awalnya ditentang oleh pemerintah pada tahun 1960an, karena dianggap berbau kebarat-baratan dan tidak nasionalis, yang oleh Bung Karno disebut musik ngak-ngik-ngok. Demikian juga para orang tua pada waktu itu menganggap musik band dapat mengganggu mental generasi muda karena penampilannya yang urakan, gondrong dan hingar bingar dalam membawakan lagu-lagu "keras." 
Sampai pada tahun-tahun 1970an dan 1980an, musik band dianggap musik kota yang membedakannya dari musik yang dianggap "kampungan" dan "pinggiran" seperti ndangdut, keroncong dsb. Perkembangan band selanjutnya menunjukkan sebagai musik yang disukai berbagai lapisan. Alat musik pendukungnya adalah gitar ritem, gitar melodi, gitar bas, keyboard, dan drum. Musik ini dimainkan dengan berbagai aliran seperti pop, rock, jazz, reggae, blues, bosas, dan sebagainya, yang diminati kaum muda. Hal ini terlihat dari maraknya grup-grup band, baik dari kelompok sekolah dan perguruan tinggi maupun dari kelompok luar lembaga pendidikan, yang membentuk diri. Musik band merupakan musik modern yang mampu mengekspresikan kemauan pemainnya, seperti terlihat ketika mereka menampilkan permainannya di panggung dengan musik hingar bingar, tata panggung, tata lampu dan kepiawaian para pemain memainkan alat musiknya. Mereka bermain sesuai aliran musiknya dan dinikmati pendukung musiknya. Personal band pada umumnya berjumlah 5-6 (lima-enam) orang (pemain bas, melodi, ritem, keyboard, drum, dan vokalis) atau lebih. Sesuai kebutuhan dan kreatifitas kelompoknya alat musik bisa ditambah dengan alat tiup, seperti saksofon dan alat musik lainnya seperti biola.

Kelompok band yang menanjak populer biasanya sudah menghasilkan album rekaman dan sering tampil di pentas komersial sedangkan kelompok yang sedang mencari nama pada umumnya tampil di ajang lomba mencari bakat, lomba yang diselenggarakan kelompok tertentu atau pemerintah serta pentas di kafe-kafe. Sekarang ini banyak sekali bermunculan kelompok band baru, khususnya yang diawaki oleh kawula muda. Bahkan, beberapa kelompok band baru sudah melejit namanya karena lagu yang mereka bawakan langsung dapat diterima oleh masyarakat. Pementasan band atau 'manggung' tidak terbatas di 
ruangan tertutup dengan panggung tinggi yang memisahkan pemain dari penontonnya, tetapi juga di ruangan terbuka tanpa panggung sehingga ada interaksi antara pemain dan penonton. Band juga tidak hanya dijumpai di tempat-tempat hiburan tertentu, melainkan bisa bermain di mana saja: di pelataran mal, tepi pantai, lapangan, halaman parkir, dan lainlain. Fenomena ini menunjukkan bahwa band benar-benar merupakan kesenian populer dan diterima masyarakat, khususnya generasi muda.

\section{3. Seni Musik Keroncong}

Pada zaman sekarang ini musik "Keroncong" sudah jarang terdengar di telinga masyarakat, bahkan anak-anak muda pun banyak yang tidak tahu keroncong itu apa dan bagaimana. Selain sudah jarang dipentaskan, musik keroncong dulunya memang dikonsumsi oleh orang-orang dewasa, bahkan sebagian warga masyarakat senior. Keroncong jenis klasik menyajikan alunan musik yang lembut dan terasa mendayu-dayu, seperti lagu "Bengawan Solo" dan "Telaga Sarangan" atau "Bandar Jakarta." Sampai dekade 1980-an pada era penyanyi kroncong kondang dari Surakarta, Waljinah dengan lagu kroncong pop Jawa "Walangkekek" dan dari Surabaya Mul Mulyadi dengan lagu "Rek Ayo Rek," keroncong pop Jawa masih sering dipentaskan dan sebagai mata pencaharian menghasilkan kesejahteraan yang cukup melimpah bagi penyanyi dan pemusiknya. Akan tetapi setelah era 1980-an musik tersebut sudah mulai redup bahkan tergeser oleh jenis-jenis musik baru dengan lagu-lagu campur sari seperti yang dinyanyikan oleh Dede Kempot, ditambah maraknya lagu-lagu Indonesia dan barat pop serta lagu-lagu ndangdut yang semakin mengalihkan perhatian masyarakat, khususnya orang muda dan dewasa. Belakangan tidak hanya musik keroncong, hampir semua kegiatan rekaman mengalami 
kerugian material, sebagai sumber mata pencaharian, oleh praktek pembajakan. Itulah beberapa penyebab musik Keroncong mengalami kemunduran setelah era 80-an.

\section{3. 1. Kelompok Keroncong "Senja '93"}

Berawal dari beberapa orang seniman yang sering berkumpul dan melakukan latihan keroncong di Jl. Sawo Jajar, Semarang, tercetuslah pemikiran salah seorang dari mereka, yang disebut sebagai "sesepuh," untuk melahirkan sebuah kelompok yang mewadahi

mereka. Almarhum Daryono ketika itu memanggil Kartiman Londo dan menyampaikan keinginannya tersebut. Setelah berbicara panjang akhirnya ditarik kesimpulan bahwa mereka memang perlu wadah dalam sebuah kelompok sendiri.

Kartiman Londo dipilih menjadi ketua kelompok dan oleh Daryono kelompok keroncong ini diberi nama Senja '93. Pemilihan Kartiman sebagai ketua mengingat umurnya yang paling muda di antara anggota lain, sehingga diharapkan dapat bekerja ekstra dalam membangun dan mengembangkan kelompok Senja '93. Tidak ada filosofi tertentu mengenai pemberian nama Senja '93, selain terinspirasi keindahan senja yang datang menjelang malam, sehingga kelompok ini diharapkan bisa menjadi indah dan dinikmati banyak orang, dengan angka kelahiran tahun '93 sebagai pengingat akan sejarah munculnya sebuah kelompok keroncong.

Di awal pembentukannya, muncul kesadaran untuk meresmikan kelompok Senja '93. Untuk itu, Kartiman mengajukan surat ke Dinas Pendidikan dan Kebudayaan (PDK) perihal pembentukan kelompok keroncong baru serta meminta diresmikan secara hukum. Tanggapan positif ternyata muncul, surat tersebut dibalas dua hari setelah pengirimannya, yang menyatakan pengesahan kelompok Senja '93 sebagai kelompok resmi. Beranggotakan 
15 (lima belas) orang, Senja '93 mulai merambah dunia pentas dan lomba-lomba. Alhasil, nama Senja '93 semakin diketahui khalayak umum dan memiliki penggemar di setiap pentasnya.

Pementasan Orkes Keroncong Senja '93 menurut Kartiman masih bersifat pentas tradisional dengan mengambil patokan kalau pentas mereka tetap menggunakan tata panggung sederhana tanpa pencahayaan seperti dalam teater. Untuk tata panggung sendiri masih dipakai sistem proscenium yang menghadap langsung ke penonton dengan jarak 1.5 (satu setengah) meter. Penggunaan lampu juga diakui masih hanya berupa penerangan biasa.

Perbedaan hanya terletak pada tembang-tembang yang mereka bawakan. Senja '93 tidak mematok bahwa mereka harus membawakan tembang keroncong lama, namun juga mengadopsi lagu-lagu pop, seperti lagu pop Pance ke dalam alunan nada keroncong. Kiat ini terbukti berhasil membuat penampilan mereka tidak membosankan. Mereka juga kerap meminta penonton menentukan sendiri lagu untuk kemudian dibawakan di atas panggung.

Senja '93 tampil di berbagai acara, seperti pesta pernikahan, khitanan, syukuran, lomba Pemerintah Provinsi dan beberapa pentas insidental. Latihan mereka lakukan selama dua jam menjelang pentas, singkatnya latihan dikarenakan mereka sudah sering berkumpul dan secara teknis sudah menguasai permainan alat musik masing-masing. Dalam satu tahun Senja '93 pentas kira-kira enam kali. Jumlah ini tidaklah selalu sama, terkadang dalam satu tahun mereka mendapat kesempatan tampil lebih banyak dan itu jarang terjadi. Frekuensi pementasan ini tentu tidak bisa menjadikan keroncong sebagai mata pencaharian mereka. Kartiman juga mengaku, mereka melakukannya demi kepuasan batin. 
Seniman, menurut Kartiman, mendapat penghargaan moril berupa apresiasi berkesenian. Seorang seniman akan puas jika sudah bisa memberikan yang terbaik di atas panggung. Kegagalan di atas panggung adalah hal yang harus dihindari. Mengenai penonton, Kartiman tidak membenarkan sistem penonton yang membayar pentasnya, "kesenian itu bukan untuk dijual, tapi dinikmati dan dilestarikan keindahannnya," ucapnya dengan menambahkan bahwa mendapat tepuk tangan dari penonton lebih bernilai daripada bayaran yang mereka dapatkan. Yang mereka inginkan adalah pentas yang bisa membuat penonton larut dan senang.

Mengenai penggemar, Senja '93 sudah pula memiliki penggemar yang tersebar di berbagai tempat di Indonesia seperti Ujung Pandang, Pati, Kendal, dan Purwokerto. Penggemar-penggemar mengetahui kelompok ini ketika melihat penampilan mereka di TVRI Jawa Tengah maupun mendengar alunannya di RRI Semarang. Wujud penghargaan yang diberikan penggemar adalah berupa apresiasi tinggi terhadap proses berkesenian. Penggemar juga sering menelepon dan meminta untuk dinyanyikan lagu kesukaan mereka. Selain itu, dukungan dari keluarga merupakan hal penting untuk membuat mereka bisa bertahan di kancah kesenian. Keluarga Kartiman sendiri memberikan dukungan penuh terhadapnya untuk bisa terus berkesenian.

Menurut Kartiman, jika kita mendengar kata "seniman," maka jangan dulu mempersepsikan semuanya melakukan dengan tujuan semata mengembangkan dan meninggikan kualitas kesenian. Namun, banyak juga yang beralasan lain dalam berkesenian seperti sekedar hobi, media hiburan, mencari popularitas, panggilan jiwa, dan yang paling banyak adalah sebagai mata pencaharian. Semua pilihan itu sah-sah saja, tidak ada pakem 
yang mengatur seorang menjadi seniman. Bila kesenian dijadikan sebagai mata pencaharian, tentu yang dianut adalah paham-paham membisniskan kesenian atau "menjual" kesenian untuk mendapatkan materi. Paham ini pada dasarnya sudah melekat di setiap orang, namun yang membedakan adalah, apakah mata pencaharian menjadi yang utama dari proses atau mengenyampingkannya dari tujuan utama, yaitu melestarikan kesenian misalnya.

Kartiman mengatakan bahwa tujuannya menggeluti dunia keroncong bukanlah dikarenakan alasan materi atau mata pencaharian, namun memang sebagai hobi dan panggilan jiwanya untuk terus menjadi seniman. Untuk membuktikan ucapannya, Kartiman menceritakan bagaimana ia akan sangat marah apabila ada penyelenggara acara yang mematok harga buat menonton pentas keroncong, karena kesenian menurutnya bukan untuk semata-mata dijual, tapi dilestarikan.

Kartiman juga tidak segan-segan ikut bernyanyi bersama pengamen keroncong bila secara tidak sengaja bertemu kelompok pengamen di suatu tempat. Tingkah ini beberapa kali dilakukannya. Sebagai ketua kelompok Senja '93 Kartiman tidak mementingkan pembagian bayaran untuknya, lebih penting baginya semua anggota kelompok yang bermain mendapat bagian. Dapat dikatakan bahwa, Kartiman dan seniman lain di Senja '93 menggeluti musiknya terutama karena panggilan nurani yang berawal dari hobi, sedangkan urusan materi tidak menjadi dasar berkesenian.

\section{3. 2. Kelompok Musik Keroncong-Rock: Congrock}

Musik Congrock sesungguhnya bukan musik keroncong, karena Congrock adalah musik keroncong yang ngerock, yaitu perpaduan antara musik keroncong dan musik rock and roll. Setidaknya itulah pengertian sederhana yang diciptakan anggota kelompok 
Congrock, yang terdengar seperti aliran baru dalam dunia musik di Indonesia, tapi sesungguhnya Congrock telah ada sejak tahun 1983. Grup musik yang beraliran Congrock ini masih jarang, mungkin baru ada satu-satunya di Indonesia. Mengapa disebut Congrock, seperti yang telah dikatakan sebelumnya, karena penonton menyebut bahwa "keroncongnya ngerock," saat melihat Congrock tampil, dan dari situlah nama Congrock berasal. Namun kata Congrock yang merupakan gabungan antara kata keroncong dan rock, bukan menunjukkan aliran musik. Congrock bisa bermain musik dengan memadukan musik keroncong dengan aliran musik apa saja, seperti rock, jazz, pop, dan lain-lain.

Congrock berasal dari kata 'keroncong' dan 'rock,' "aliran musik campuran" antara keroncong dan rock ini lahir dari sebuah komunitas mahasiswa Universitas 17 Agustus (UNTAG) Semarang, pada tanggal 17 Mei 1983. Berawal dari kumpul-kumpul bersuasana santai, muncullah ide untuk membuat grup musik unik dan nyentrik yang belum pernah ada. Kemudian dari kumpul-kumpul itu, diambil kesepakatan untuk mengambil aliran keroncong yang dimodernisasikan. Laiknya kelompok musik lain, kelompok ini pun mengalami pasang surut, seperti gonta-ganti, berganti personil yang tak terhindarkan. Sekitar tahun 1984, masuklah Budi (biola), kemudian Anang (bass), Ninik (biola), serta Rifai (flute); kemudian pada tahun 1985, Bambang Kempos (vokal) bergabung dalam grup musik ini dan pada tahun 1986, saat pentas dalam acara Sejuta Bintang di Gedung Olah Raga (GOR) Jawa Tengah (kini komplek Mal Ciputra) bersama artis Jakarta, penonton yang hadir sangat responsif, dan mengatakan 'keroncong-e nge-rock' - dan sebutan musik keroncong yang ngerock jadi perbincangan banyak orang. Dari perbincangan itu, akhirnya terjelma nama “Congrock 17." 
Di tengah melesatnya perkembangan "Congrock 17," muncullah pendapat pro dan kontra terhadap kelompok aliran musik ini. Ada yang menuding Congrock sebagai 'perusak' musik keroncong; bahkan TVRI Jakarta pernah menolak Congrock untuk tampil di acara "Aneka Ria" dengan alasan tidak jelas, walaupun akhirnya Congrock bisa tampil di acara "Lacak Dunia" yang tidak cocok untuk acara musik. Di sisi lain, pihak yang mendukung keberadaan kelompok musik itu ternyata juga tidak sedikit. Alasan mereka, Congrock masih setia menyisipkan idiom-idiom keroncong di dalamnya. Dengan dukungan itu, Congrock pun terus menunjukkan eksistensinya dalam berkarya.

Pada tahun 1990, Congrock mulai menembus dapur rekaman. Dengan mengusung 12 (dua belas) lagu yang berlabel "Gadis Yang Mana" Congrock memasuki dapur rekaman Puspita Record Jakarta dan dibantu musisi kawakan Awang Arifin. Tanggapan terhadap album Congrock cukup baik, nama Congrock semakin dikenal di Indonesia, sampai-sampai saat diminta untuk masuk dapur rekaman lagi, Congrock selalu tidak siap karena kebanyakan order pentas.

Dari panggung pentas ini Congrock mendapatkan banyak teman beberapa artis nasional, seperti Idang Rasyidi, Ireng Maulana, Vonny Sumlang, Bangkit Sanjaya, Titik Puspa, Henny Purwonegoro, Ully Sigar Rusadi, Indro Warkop, dan lain-lain. Titiek Puspa yang sangat terkesan dengan grup musik ini, mengajak Congrock keliling Eropa dan Amerika Latin selama satu bulan penuh pada tahun 1994. Ini dilakukan dalam rangka misi kebudayaan Indonesia yang disponsori oleh Kedutaan Besar negara-negara tersebut.

Sampai saat ini, Congrock memegang teguh pada komitmen awalnya, tidak perlu dipertanyakan lagi. Terbukti dengan semakin bertambahnya penggemar Congrock. Selain 
itu, Congrock tidak hanya berkarir di kota Semarang saja, tapi juga di tingkat nasional bahkan sempat ke luar negeri. Para penggemar Congrock meliputi berbagai kalangan penggemar musik termasuk keluarga, sahabat, dan sesama seniman. Orang-orang inilah yang selalu memberikan semangat dan motivasi mereka untuk perkembangan Congrock ke arah yang lebih baik. Selain dari orang-orang yang telah disebutkan sebelumnya, pemerintah pun memberikan dukungan. Namun hal ini tidak berlangsung lama.

Pada awalnya saat personil Congrock masih duduk di bangku kuliah, pemerintah membantu mereka dengan memberi beasiswa kepada para personilnya sebagai wujud apresiasi terhadap kreatifitas mereka. Kemudian setelah lulus dari bangku kuliah, beberapa personil Congrock mendapat tawaran pekerjaan dari pemerintah untuk ikut bergabung di instansinya. Hal itu dikarenakan mereka dikenal sebagai mahasiswa berprestasi di bidang seni. Namun di masa sekarang ini, dukungan pemerintah pada Congrock memudar karena hal yang tidak diketahui dengan jelas. Walaupun perhatian pemerintah pada Congrock memudar, semangat Congrock tidak berkurang, karena bermusik adalah kegiatan yang sangat mereka senangi, sehingga apapun yang terjadi, tidak akan berpengaruh pada kesenangan mereka dalam bermusik. Personil Congrock menganggap, berkesenian mereka adalah sebagai hobi dan sebagai wadah mengekspresikan bakat dan dorongan seninya; jadi tidak semata-mata sebagai mata pencaharian.

Personil Congrock menganggap, kegiatan mereka dalam grup Congrock bukan merupakan suatu kewajiban, tapi lebih kepada kesenangan yang menimbulkan rasa puas dengan dorongan sendiri untuk bermusik. Beruntungnya, dorongan kesenangan dalam diri ini dapat "menghasilkan," dengan adanya panggilan manggung di berbagai acara 
berkesenian. Pementasan Congrock dapat dikatakan tidak menentu, tergantung permintaan. Biasanya Congrock dipanggil untuk meramaikan acara-acara seni seperti Festival Gong Tugu Muda Semarang, Acara Rendezvoices Share Sound-Share Earth, serta pementasanpementasan lain di dalam dan di luar negeri. Selain itu, Congrock diminta untuk mengiringi artis ibu kota seperti Titiek Puspa, dan menjadi bintang tamu dalam acara yang diadakan oleh pemerintah, atau suatu organisasi. Selain pernah dipanggil oleh Presiden Susilo Bambang Yudhoyono untuk menyanyi di Istana Negara, pada perayaan 17 Agustus 2006, Congrock memiliki kegiatan rutin yaitu tampil di TVRI setiap bulannya pada hari Minggu, pada minggu keempat.

\section{Simpulan}

Berkesenian merupakan bagian dari kebutuhan hidup manusia. Di sela-sela rutinitasnya dalam memenuhi kebutuhan hidup, manusia tetap mencari keseimbangan lahir dan batin, yang salah satu bentuknya adalah berkesenian. Melalui kegiatan seni, manusia dapat mengekspresikan ungkapan jiwa, rasa, keinginan, dan kesenangannya. Kebutuhan untuk berkesenian ini tidak terbatas pada masyarakat yang sudah mapan secara ekonomi dan status sosial saja, tetapi juga menghinggapi mereka yang lazim dikategorikan sebagai masyarakat golongan "menengah" dan golongan "bawah." Bahwa jenis kesenian yang diminati oleh masyarakat golongan "atas" pada umumnya berbeda dari kesenian yang diminati oleh masyarakat golongan-golongan "menengah" dan "bawah" memang tidak dapat dipungkiri. Dalam tulisan ini terungkap bahwa seni tradisional dan seni populer memiliki komunitas sendiri-sendiri. Oleh karena itu, perkembangan tiap-tiap jenis kesenian 
pentas tersebut juga sangat bergantung pada sikap komunitasnya. Simpulan dapat disampaikan sebagai berikut.

Beberapa jenis kesenian pentas tradisional, seperti sintren, cowongan, lengger (atau ronggeng, tayub, ledhek, tledhek), kuda lumping, ebeg, dan kethoprak masih dapat dijumpai di daerah-daerah tertentu karena generasi tertentu, terutama generasi senior, masih merasa memiliki kesenian tersebut dan dengan ikhlas masih berupaya menghidupkan kesenian tersebut. Pelaku kesenian tradisional tersebut merasa memiliki kewajiban sekaligus panggilan jiwa untuk tetap melestarikan kesenian yang pada umumnya mereka warisi secara turun-temurun dan mengupayakan regenerasi. Keakraban mereka terhadap cabang-cabang kesenian pentas tersebut menyebabkan rasa memiliki yang dalam. Mereka tidak peduli apakah dalam berkesenian itu mereka mendapat imbalan materi yang memadai atau tidak; dan kenyataannya, sejumlah kesenian pentas tersebut memang tidak dapat diandalkan sebagai mata pencaharian. Penyebabnya antara lain adalah penikmatnya yang semakin lama semakin berkurang. Selain itu, pemetasan dengan frekuensi yang tidak menentu dan imbalan yang relatif rendah menyebabkan jenis-jenis kesenian tersebut tidak mungkin diandalkan sebagai upaya pemenuhan kebutuhan hidup sehari-hari. Dengan sedikit perkecualian terdapat kelompok kesenian pentas kethoprak yang berhasil menjadi sumber penghasilan tambahan, sebagai mata pencaharian yang menghasilkan keuntungan material, dengan pengelolaan yang dianggap profesional. Namun demiikian, seiring dengan proses beralihnya generasi, cabang kesenian pentas ini pun mulai terpinggirkan dan mulai tergerus oleh bentuk kesenian populer industrial massif.. 
Beberapa jenis kesenian yang sekarang ini dapat dijadikan sebagai mata pencaharian adalah kesenian yang sederhana dan mengikuti selera pasar, seperti dalam bentuk organ tunggal. Kesenian ini simpel karena hanya melibatkan beberapa pelaku seni dengan peralatan yang tidak begitu banyak. Kesenian ini dapat mengikuti selera pasar karena bentuk utama dari kesenian ini adalah seni vokal yang lagu-lagunya dapat berasal dari berbagai genre, mulai dari lagu jawa, pop, campur sari, keroncong, dangdut, sampai lagu-lagu dari manca negara. Di samping itu, kesenian ini dapat dinikmati oleh masyarakat dari berbagai kalangan. Sementara itu kelompok-kelompok band yang menjamur di perkotaan pada umumnya diawaki dan digemari kaum muda "sekolahan" mengalami pasang-surut popularitas, sangat tergantung dari keberhasilan mereka mempertahankan dan mengembangkan kelompoknya. Tak kalah menarik adalah munculnya revival kelompok musik berbasis keroncong yang dikemas dan diwarnai genre aliran rock yang belum berkembang sebelumnya sehingga kelompok yang populer dengan Congrock menjelma fenomena akhir abad ke-20 yang tetap hidup hingga sekarang. Dari pelajaran ini dapat diyakinkan bahwa formula strategis agar kesenian pentas genre lama diminati lagi adalah kreatifitas dan pembaharuan, jika perlu dengan upaya pemaduan antar jenis atau genre kesenian pentas - sekalipun strategi demikian belum menjamin keberhasilan keberlangsungan dan keberlanjutannya.

Dalam masyarakat berkembang, kesenian pentas berkembang tak menentu. 


\section{Daftar Pustaka}

Bernard, H. Russell. 1988. Research Methods in Cultural Anthropology. London: Sage. 1994. Research Methods in Anthropology. Qualitative and Quantitative Approaches. London: Sage.

Ellen, R. F. 1984. Ethnographic Research. London: Academic Press.

Freilich, Morris. 1983. The Pleasures of Anthropology. New York: Mentor Book.

Geertz, Clifford. 1973. The Interpretation of Cultures. New York: Basic Books. . 1989. "Being There, Writing Here," Dialogue No. 84/2.

Glasser, Barney G. and Anselm Strauss. 1967. The Discovery of Grounded Theory: Strategies for Qualitative Research. New York: Aldine Publishing Company.

Greenberg, Clement. 1961. Art and Culture. Critical Essays. Boston: Beacon Press.

Hall, James B. and Barry Ulanov. 1972. Modern Culture and the Arts. New York: McGraw-Hill Book Company.

Hammersley, Martyn and Paul Atkinson. 1983. Ethnography: Principles in Practice. London: Tavistock.

Howard, Michael C. 1989. Contemporary Cultural Anthropology. Glenview, Ill.: Scott, Foresman and Company.

Jary, David \& Julia Jary. 1991. Collins Dictionary of Sociology. Glasgow: Harper Collins.

Kayam, Umar. 1983. "Dialog antara Ilmu dan Seni," dalam Nurdien H. K., ed. Perubahan Nilai-Nilai di Indonesia. Bandung: Alumni.

Koentjaraningrat. 1974. Kebudayaan, Mentalitas dan Pembangunan. Jakarta: Gramedia. 1984. Kebudayaan Jawa. Jakarta: PN Balai Pustaka.

Kompas.com Kamis, 18 Juni 2009. "Pewarisan Budaya Daerah Tak Boleh Berhenti."

Layder, Derek. 1993. New Strategies in Social Research. Cambridge: Polity.

Masyhuril, Sigit. 2009. "Perubahan Apresiasi Masyarakat terhadap Kesenian Tradisional." Skripsi Universitas Islam Negeri Sunan Kalijaga. Yogyakarta: Perpustakaan Digital UIN Sunan Kalijaga.

Nurdien H. K., ed. 1983. Perubahan Nilai-Nilai di Indonesia. Bandung: Alumni.

Puguh, Dhanang Respati. 2009. "Dari Pakeliran Adiluhung ke Pakeliran GlamourSpektakuler: Pertunjukan Wayang Kulit Purwa Gaya Surakarta dalam Perubahan Budaya," International Seminar - Traditional Performing Art under Cultural Change: Comparative 
Study of Asian Countries. Center for Asian Studies, Faculty of Humanities Diponegoro University and Asian Culture Research Institute Toyo University Japan, Semarang, 6 August.

Rohidi, Tjetjep Rohendi. 2000a. Kesenian dalam Pendekatan Kebudayaan. Bandung: STISI Press. . 2000b. Ekspresi Seni Orang Miskin. Bandung: Penerbit Nuansa.

Sieber, Sam D. 1973. "The Integration of Fieldwork and Survey Methods," American Journal of Sociology. Vol. 78, No. 6, pp. 1335-59.

Soedarsono, R. M. 1999. Seni Pertunjukan Indonesia di Era Globalisasi. Jakarta: Direktorat Jenderal Pendidikan Tinggi, Departemen Pendidikan dan Kebudayaan.

Spradley, James P. 1979. The Ethnographic Interview. New York: Holt, Rinehart \& Winston. 1980. Participant Observation. New York: Holt, Rinehart \& Winston.

Sundberg, Norman D. 1977. Assessment of Persons. New Jersey: Prentice-Hall.

Wardoyo. 2007. "Pengembangan Bentuk Penyajian Kesenian Tradisional Emprak Sido Mukti di Desa Kepuk Kecamatan Bangsri Kabupaten Jepara." Skripsi, Semarang: Fakultas Bahasa dan Seni Universitas Negeri Semarang.

Williams, Thomas Rhys. 1967. Field Methods in the Study of Culture. New York: Holt, Rinehart and Winston.

\section{Dari jaringan internet}

Dinas Informasi dan Komunikasi Pemprov Jatim. 2010. (http://www.d-infokomjatim.go.id/news_poy.pjp?id=11\&t=315). Diakses 3 Maret 2010.

Dinas Pariwisata Jawa Tengah. 2010. (http://www.central-java-tourism. Com/en/ dancing-jepara.php).

Haryono, Didik. 2008. "Pelaku Seni Cokekan Magetan di Tengah Maraknya Musik Modern: Berangkat setelah Subuh, Sehari Bisa Dapat Rp. 50 Ribu.” Posted on Mei 13, 2008 by Brangwetan, dari Radar Madiun, Selasa, 13 Mei.

http://organisasi.org/Sun, 29/10/2006. Diakses 3 Maret 2010.

Indospritual.com. 2010. (http://www.indospiritual.com/artikel_sintren-mistis-asalcirebon.htm). Diakses tanggal 2 Maret 2010.

Kompas.com. 2008. (http://m.kompas.com/xl/read/data/2008.08.21.01264240).

Komunitas Warteg. 2010. (http://www.warteg.or.id/v4?/pilh=news\&aksi= lihat\&id=82). Diakses tanggal 3 Maret 2010.

Metronews.com.2010. (http://metronews.com/blog/dewipuspa/2010/etika-sintren-taklagi-berdaya-magis). Diakses 2 Maret 2010. 
Poer, Blontank. Jumat 22 Juli 2005. "Barongan in the Mystical Life of Blora."The Jakarta Post.

(http://www.thejakartapost.com/news/2005/07/22/039barongan-mystical-lifeblora.html). Diakses 3 Maret 2010.

Toyamaips2.blogspot.com. 2009 (http://toyamaips2.blogspot.com/2009/01/senibarong.html). Diakses 3 Maret.2010.

Tuksibedug.blogspot.com. 2009.

(http://tuksibedug.blogspot.com/2009/09/kesenian-cokekan-dan-macapatan. html). Diakses 3 Maret 2010.

Unnes.ac.id. 2010. (http://digilib.unnes.ac.id/digilib/collect/skripsi/archives/ HASH 017b/89cc88a1. dir/doc.pdf). Diakses 3 Maret 2010.

\section{LAMPIRAN \\ FOTO-FOTO PEMENTASAN KESENIAN}

\section{Sintren Dukuh Sirau, Pemalang}




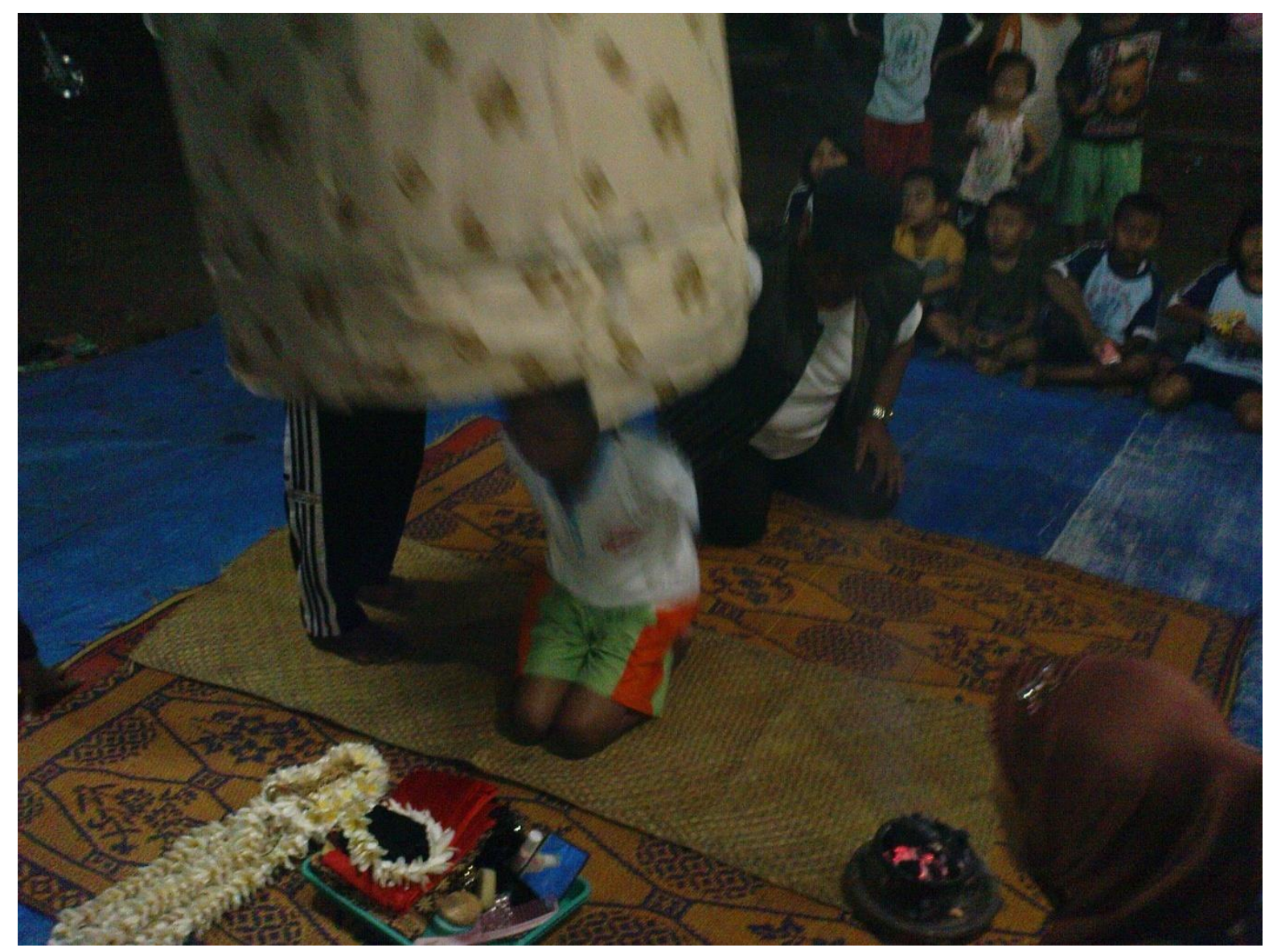

Foto 1. 1. Dalam keadaan terikat perawan Sintren masuk kurungan (Foto lapangan: Maghfiroh Agustina/Koleksi NHK). 


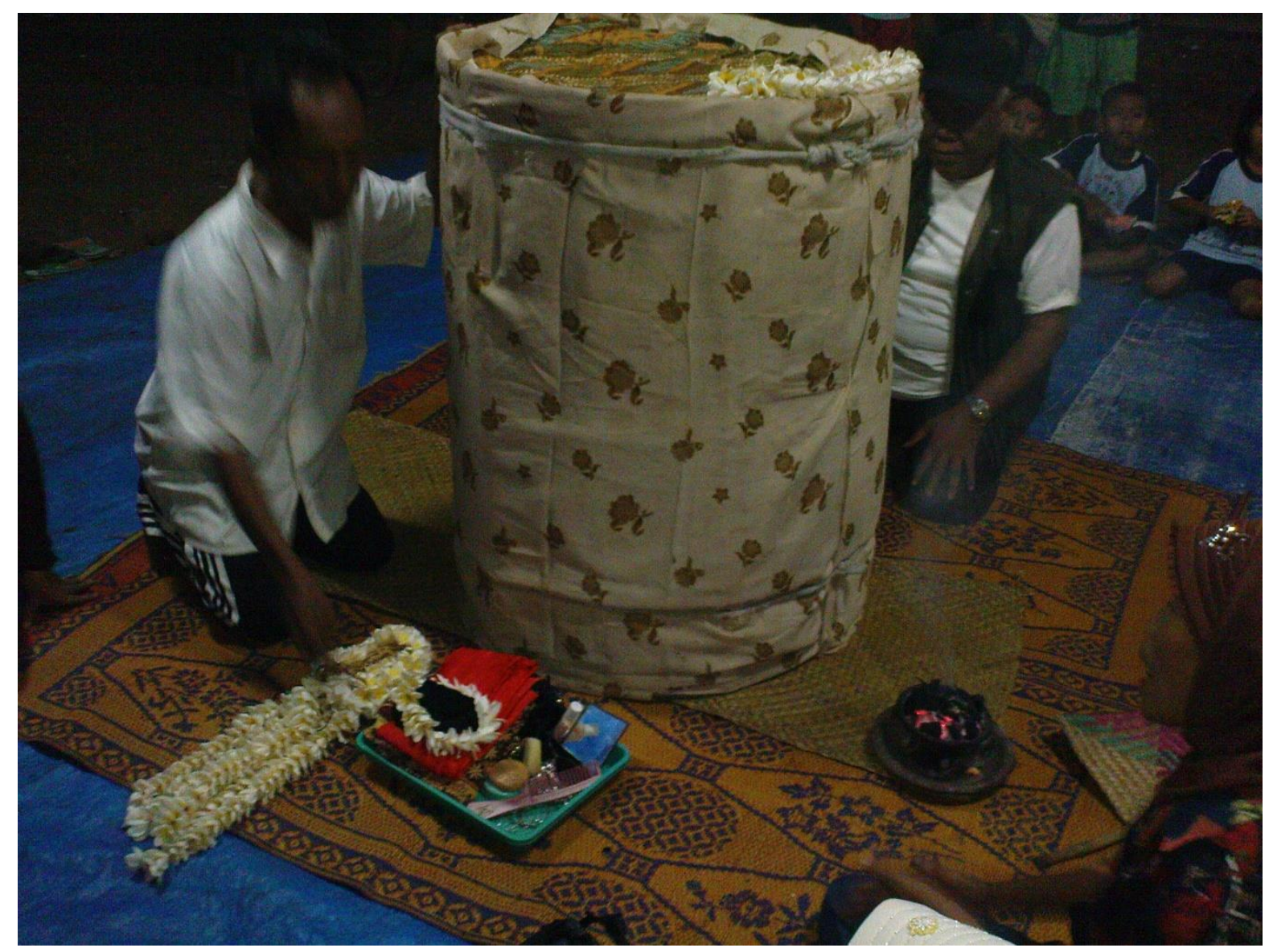

Foto 1. 2. Dibacakan mantera (Foto lapangan: Maghfiroh Agustina/Koleksi NHK). 


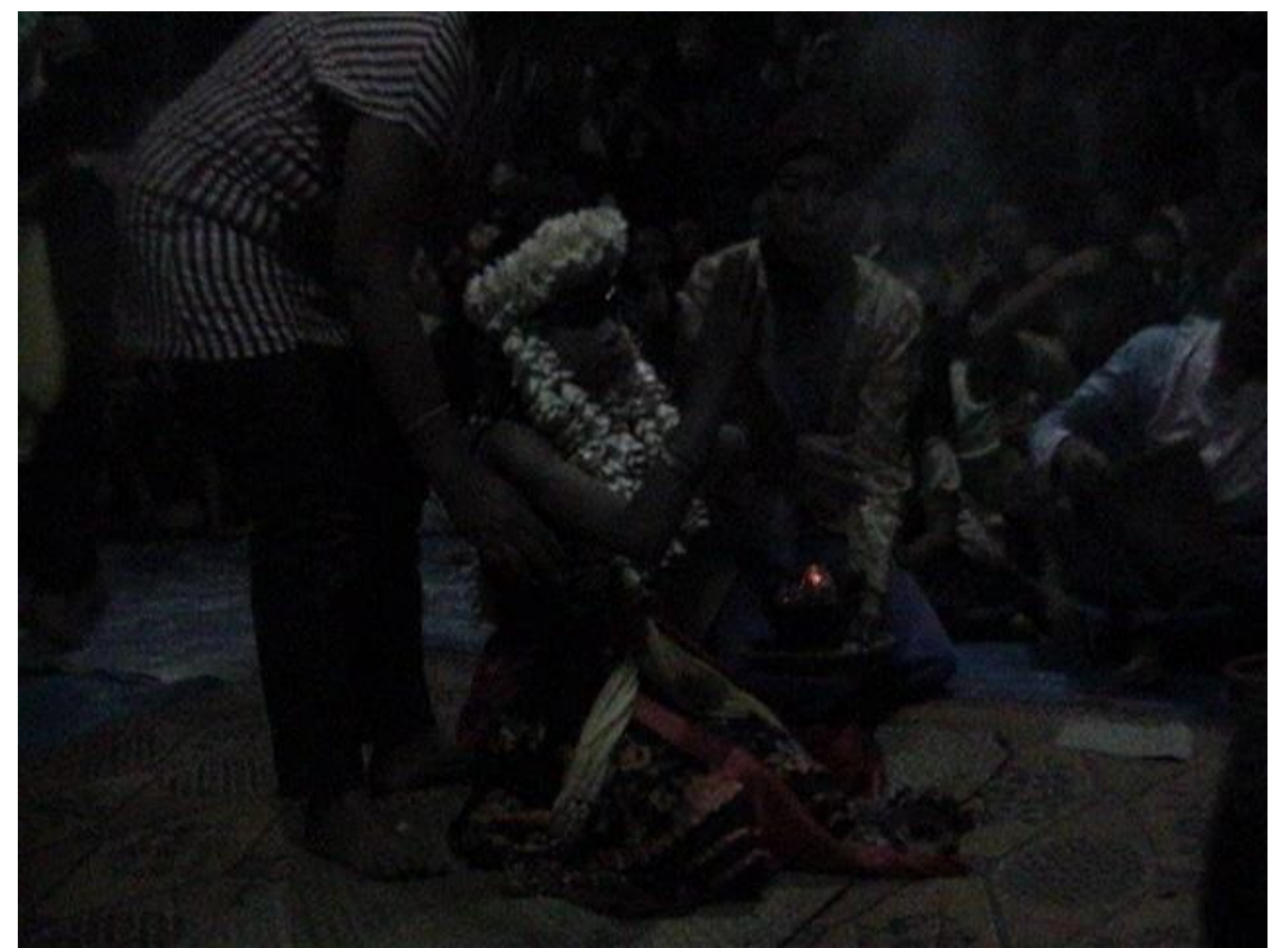

Foto 1. 3. Keluar dari kurungan sudah berpakaian penari sintren dan menyampaikan salam hormat (Foto lapangan: Maghfiroh Agustina/Koleksi NHK). 


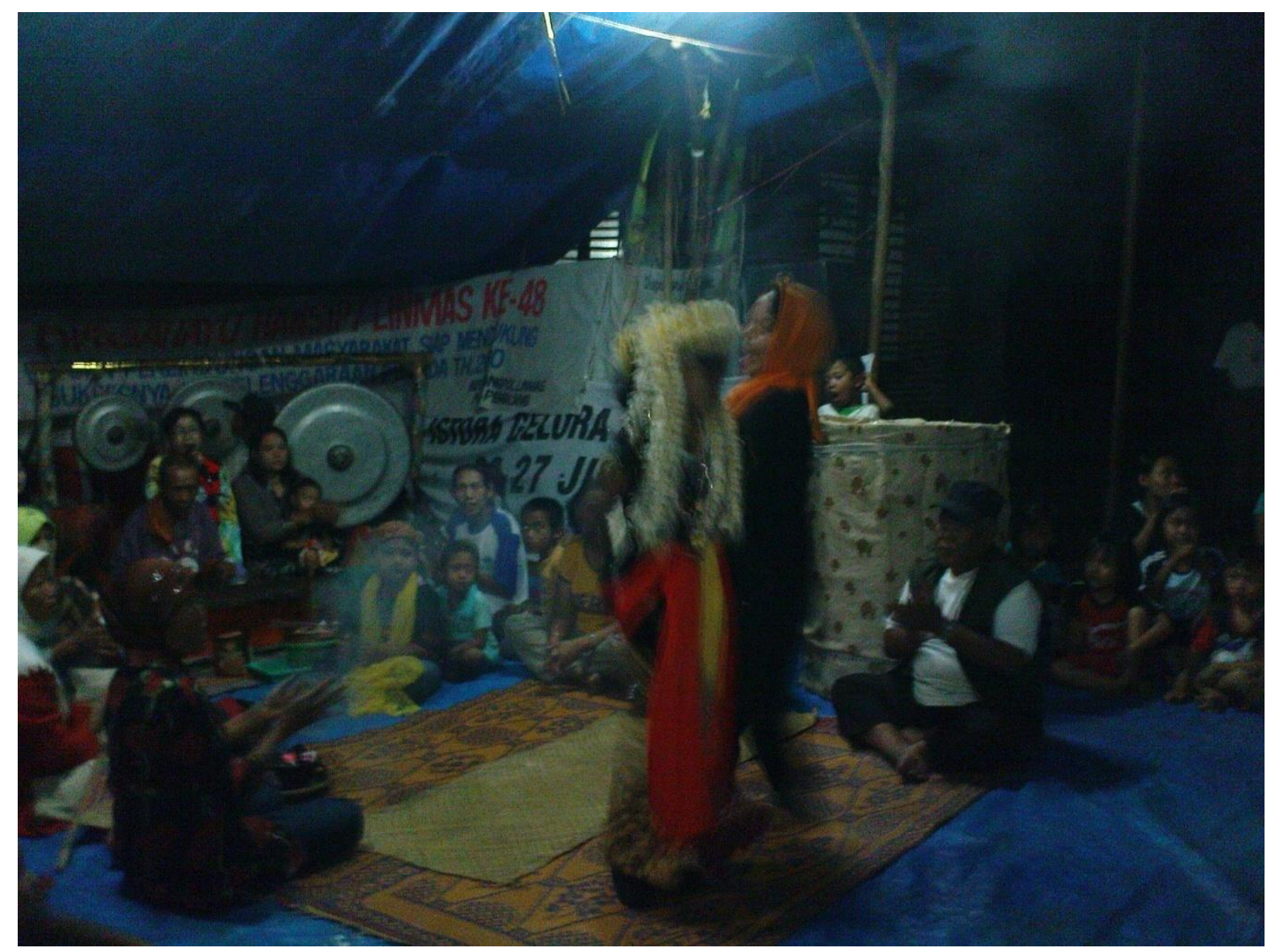

Foto 1. 4. Menari dengan iringan musik dan tembang (Foto lapangan: Maghfiroh Agustina/Koleksi NHK). 


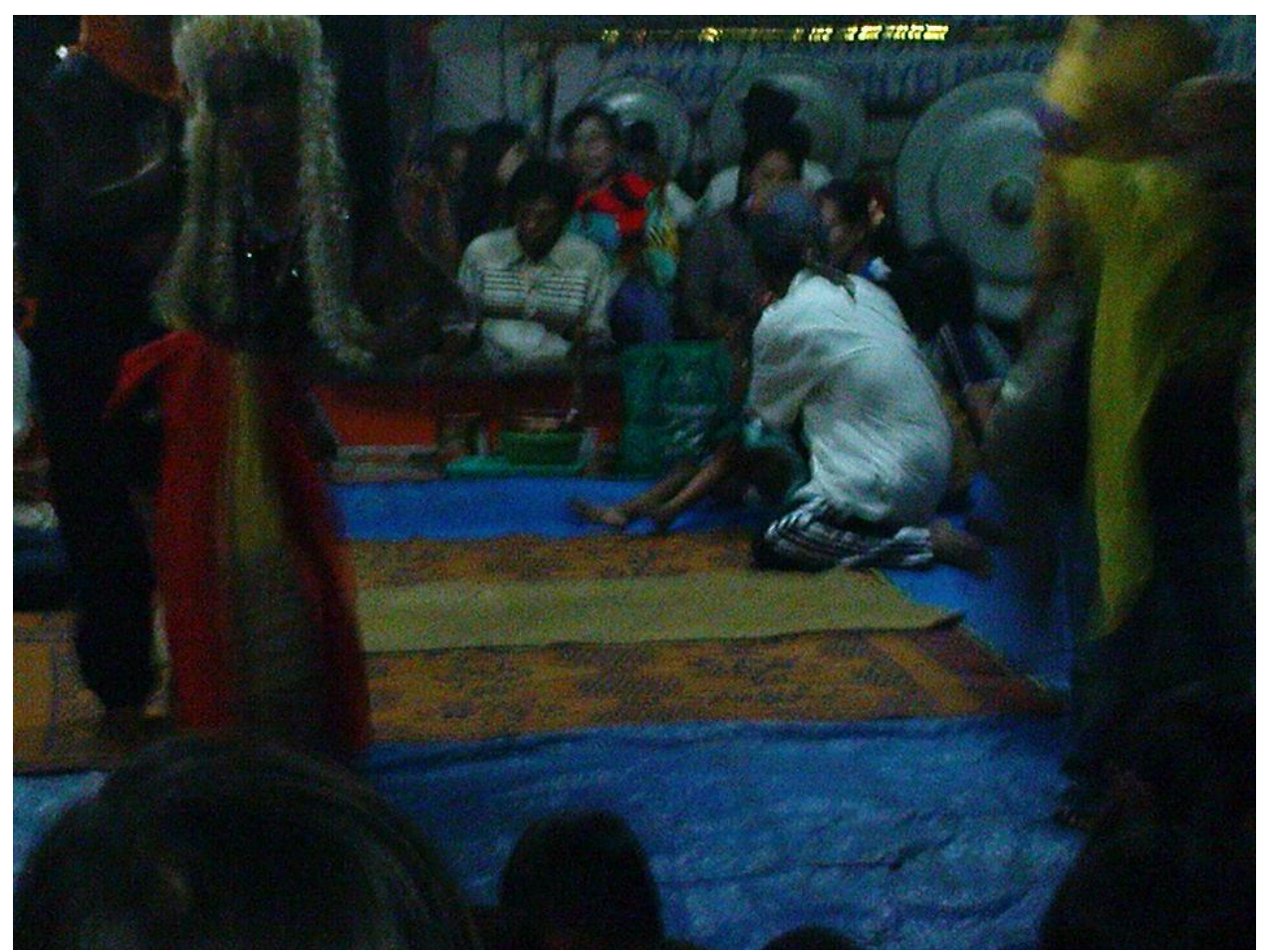

Foto 1. 5. Diiringi musik dan penari pengiring (Foto lapangan: Maghfiroh Agustina/Koleksi NHK).

2. Ebeg 


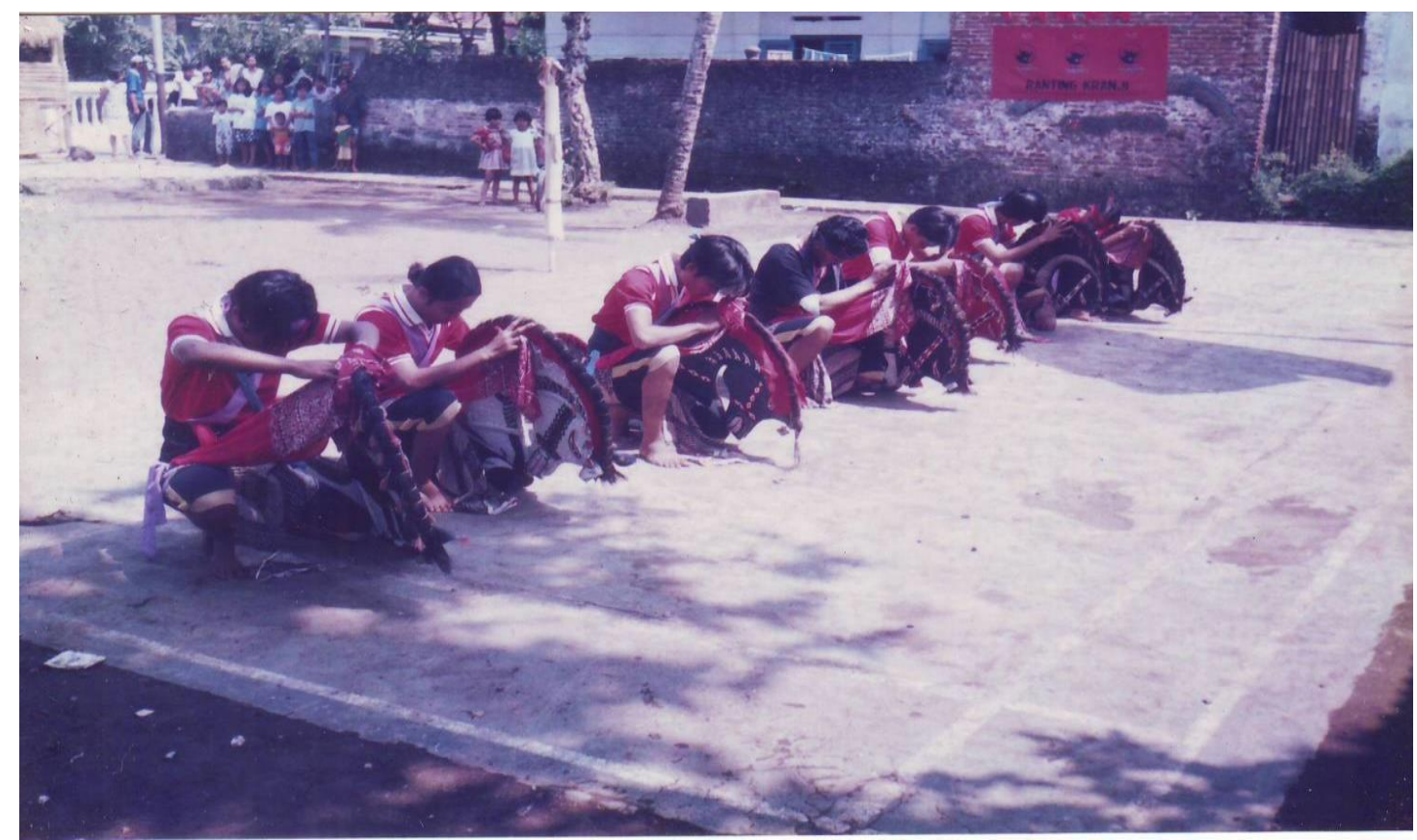

Foto 2. 1. Memulai pertunjukan Ebeg (Koleksi peneliti lapangan Imam Suhardi).

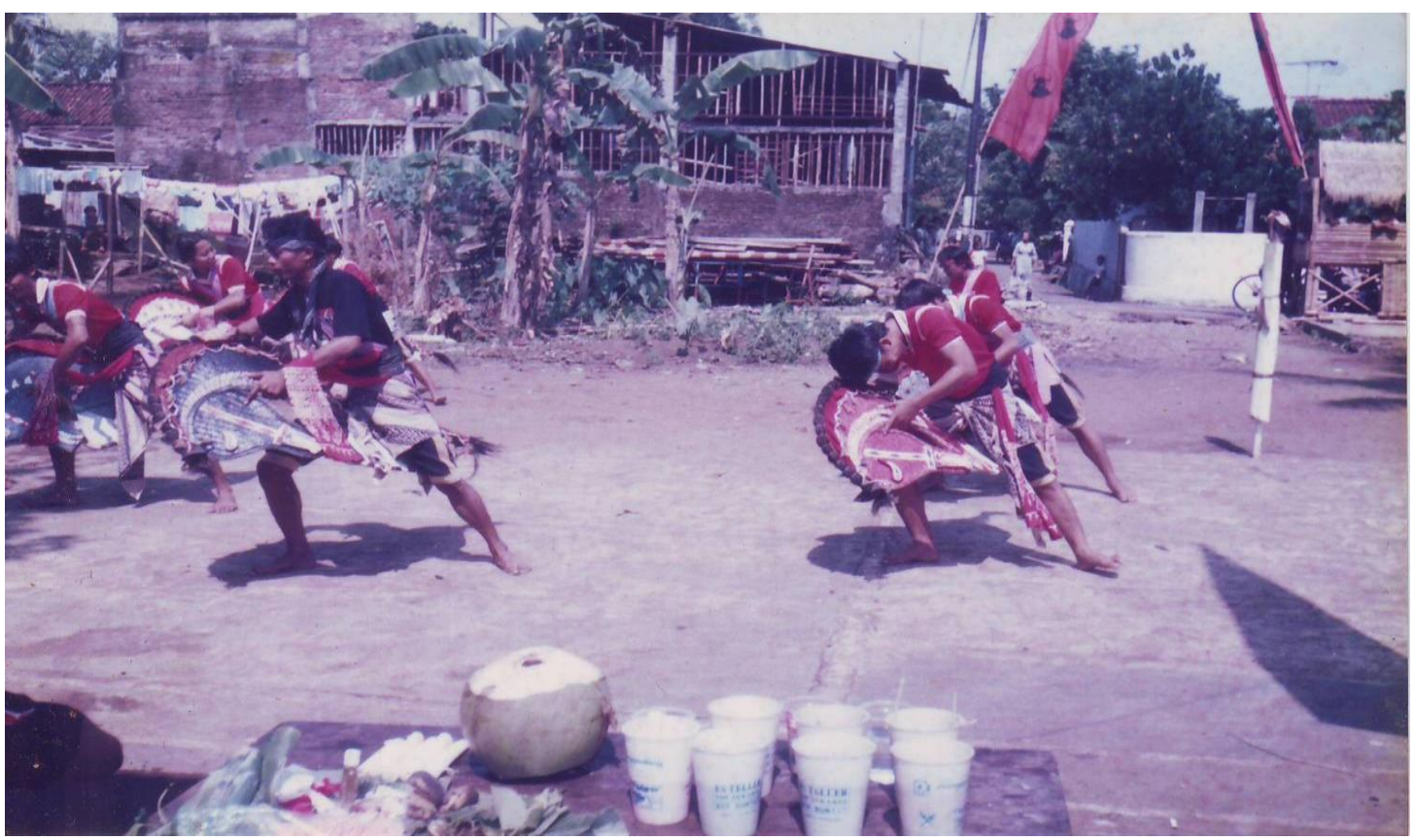

Foto 2. 2. Tarian Ebeg (Koleksi peneliti lapangan Imam Suhardi).

\section{Kethoprak}




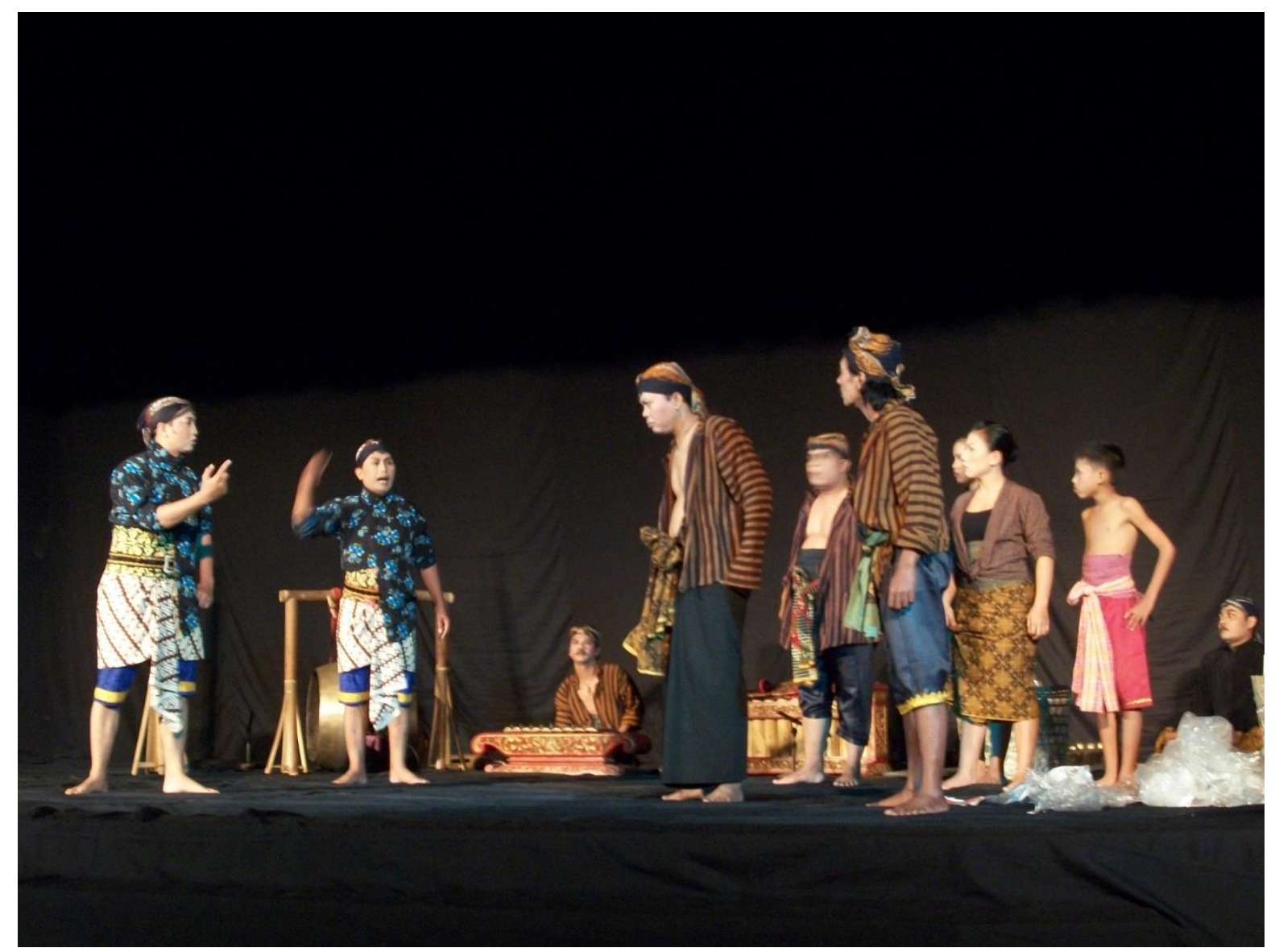

Kethoprak sebagai media tradisional (Foto lapangan NHK).

\section{Emprak Jepara}




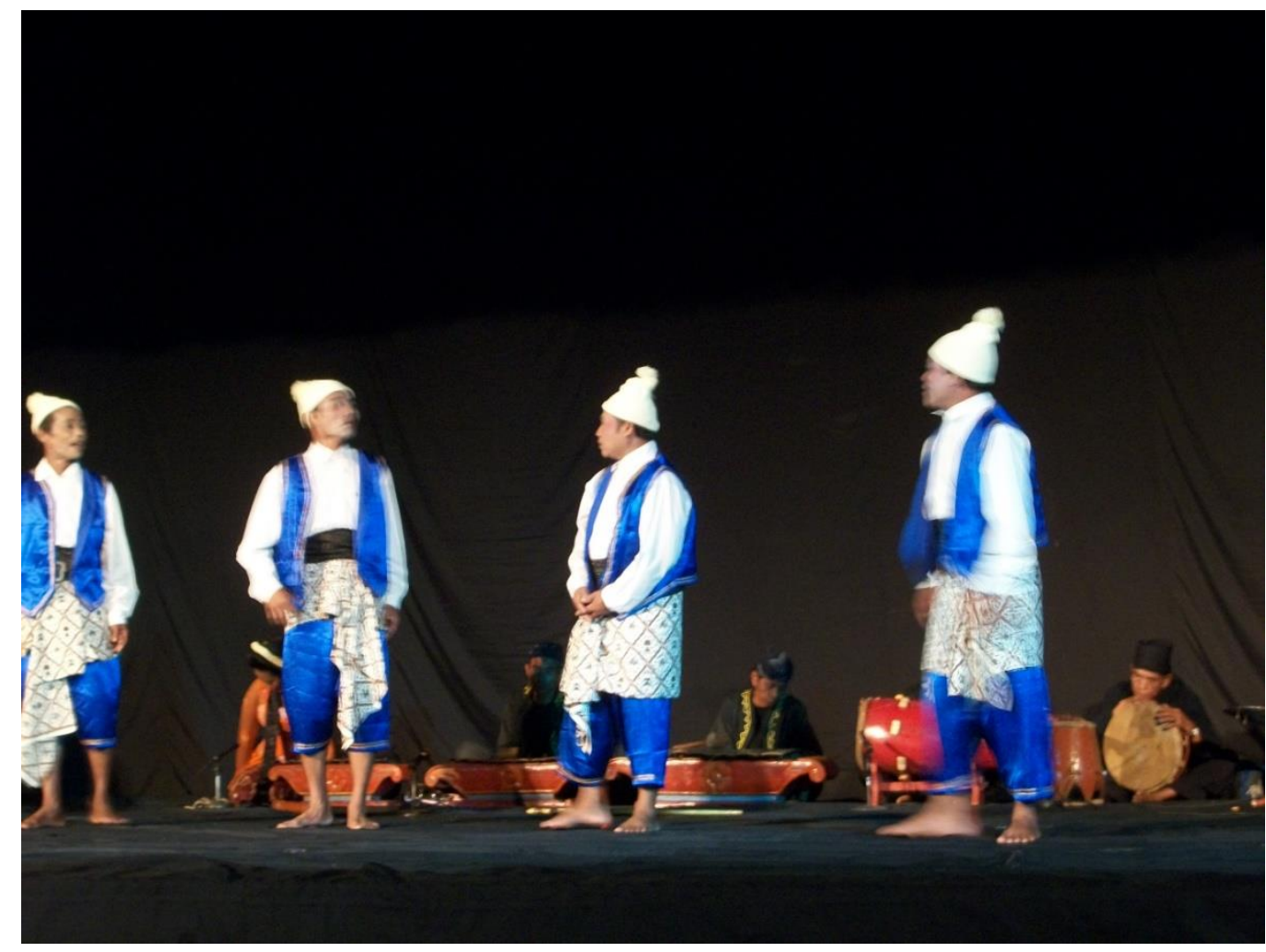

Emprak Jepara dalam pementasan di Auditorium Radio Republik Indonesia Semarang (Foto lapangan NHK). 


\section{Jaranan jalanan}

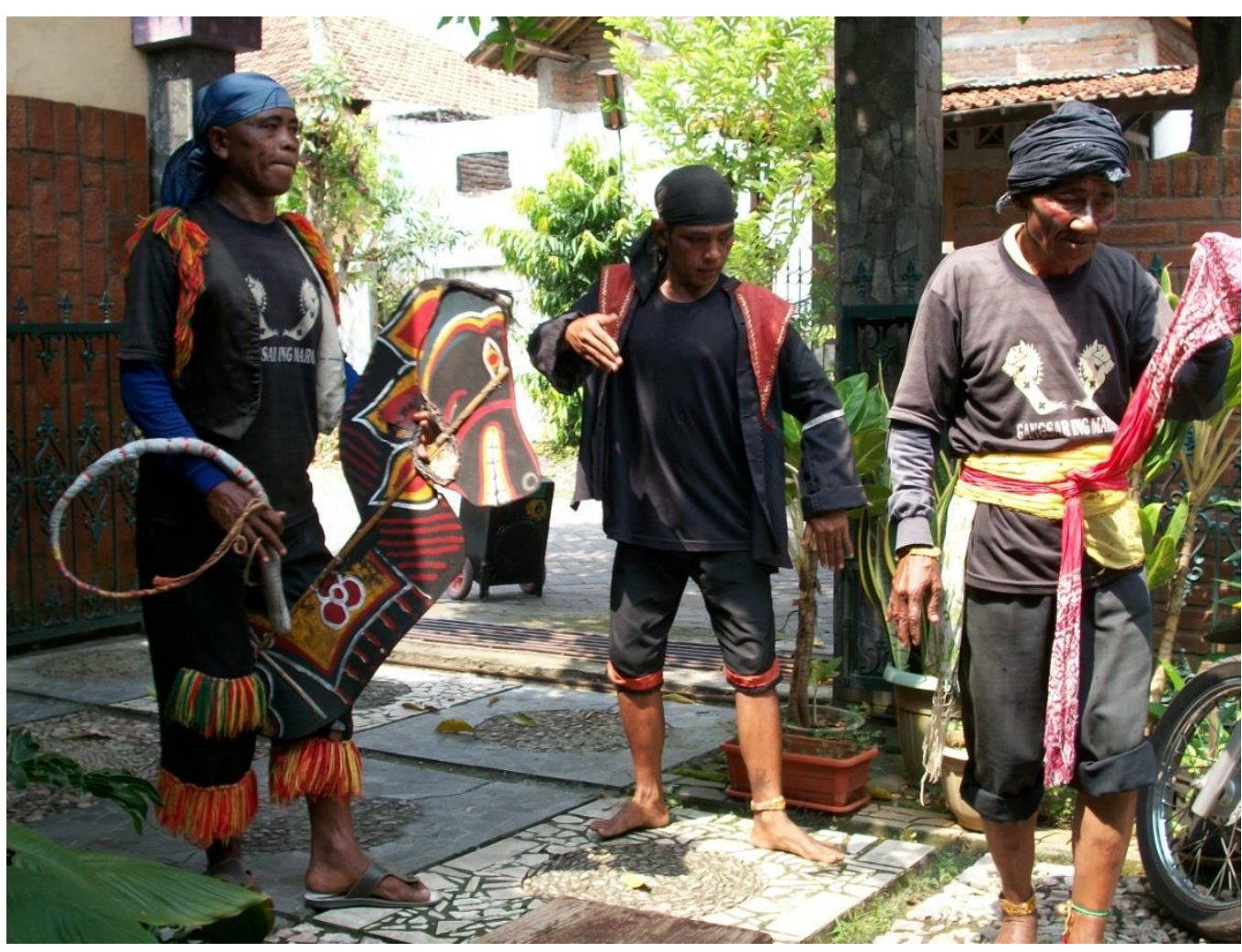

Jaranan jalanan di halaman depan rumah (Foto NHK). 


\section{Keroncong Rock, Congrock}

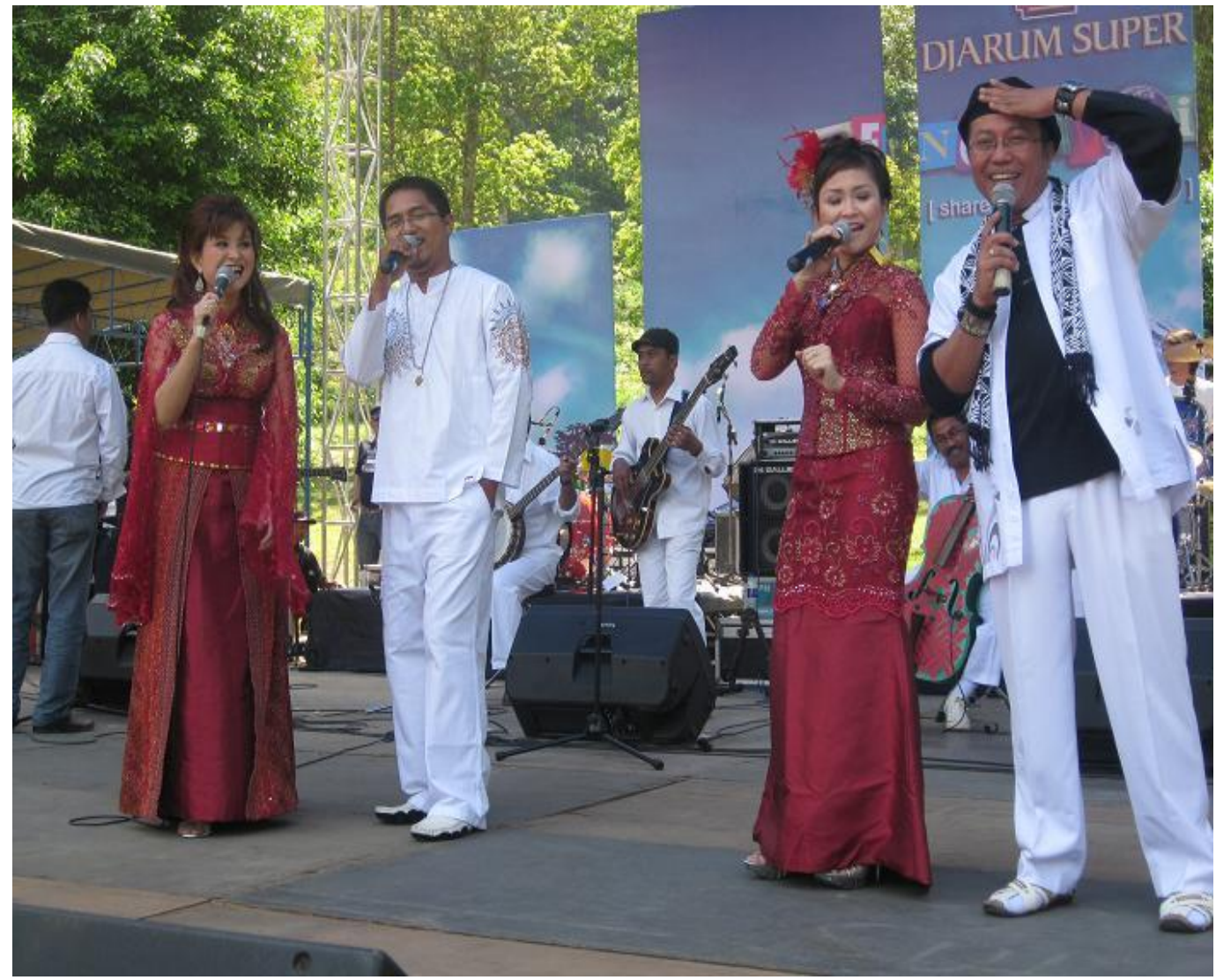

6. 1. Pementasan Congrock

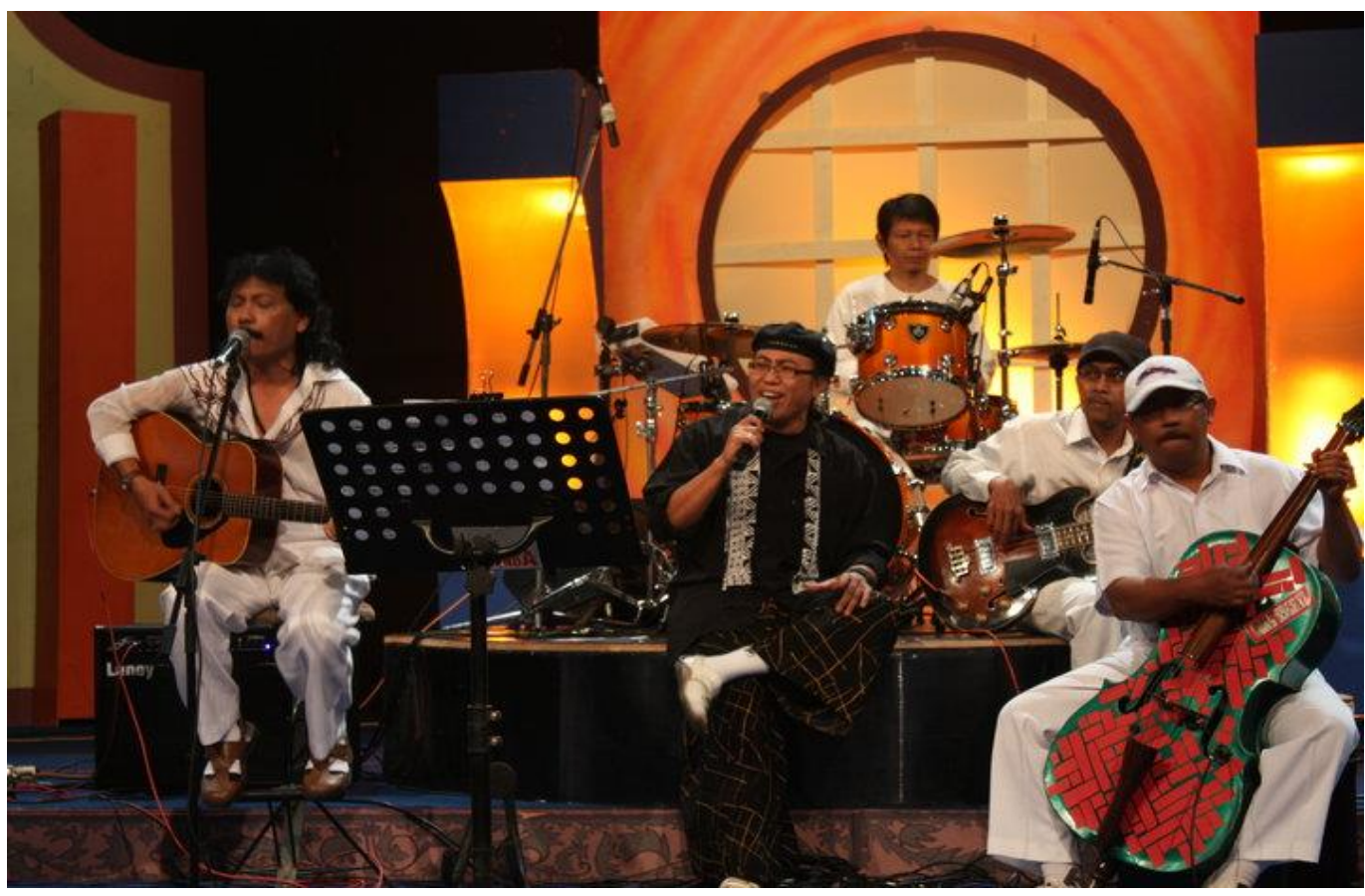


6. 2. Congrock dalam siaran di stasiun televisi 